\title{
Observations of Blocking-Induced Convergence Zones and Effects on Precipitation in Complex Terrain
}

\author{
DOUGLAS A. WESLEY and ROGER A. PIELKE \\ Colorado State University, Department of Atmospheric Science, Fort Collins, CO 80523 \\ (U.S.A.) \\ (Received January 23, 1989; accepted May 12, 1989)
}

\begin{abstract}
Wesley, D.A. and Pielke, R.A., 1990. Observations of blocking-induced convergence zones and effects on precipitation in complex terrain. Atmos. Res., 25: 235-276.
\end{abstract}

Through an extensive set of observations, including standard surface measurements, Doppler radar, routine National Weather Service radiosondes and special Cross-chain Loran Atmospheric Sounding System (CLASS) data, two case studies of wintertime storms on the east slopes of the Rocky Mountains of Colorado are presented (9-10 February 1988 and 30-31 March 1988). The emphases are the effects of blocking-induced convergence zones on snowfall distributions, snow crystal production mechanisms and banded reflectivity structure. As shown by the analysis of a typical Front Range storm, cold air damming can frequently lead to convergence zones and enhanced precipitation east of the mountains. The meso-fronts often form in place just east of the foothills, and are sensitive to the nature of the low-level synoptic easterly flow. For other upslope situations, the convergence zone does not appear as a meso-front, but as a less distinct area of convergence. Measured vertical profiles associated with the blocked surface patterns reveal a distinctly layered temperature and wind structure. These soundings, along with surface measurements of wind, moisture and snow crystal types, enable some microphysical interpretation to be made concerning snowfall production in zones of ascent aloft, which are related to frontal surfaces as well as lifting at the top of the blocking-induced cold pool. Predominance of heavily rimed, dendritic aggregates implies lifting associated with the layered vertical structure in both storms. Bands of enhanced Doppler reflectivity exhibit significant correlation with snowfall intensity. The two case studies demonstrate that distinctly different patterns of blocking and convergence can appear in Colorado Front Range storms, each resulting in a unique snowfall distribution.

\section{RESUME}

A l'aide d'un ensemble fourni d'observations, incluant des mesures classiques au sol, des données de radar Doppler, des radiosondages du réseau du National Weather Service, et des sondages spéciaux du "Cross-chain Loran Atmospheric Sounding System" (CLASS), on présente deux études de cas de perturbations hivernales sur la pente orientale des Montagnes Rocheuses du Colorado (9-10 février 1988, et 30-31 mars 1988). On montre spécialement les effets des zones de convergence induites par blocage sur la distribution des chutes de neige, les mécanismes de production des cristaux de neige, et la structure en bande de la réflectivité. Comme le montre l'analyse d'une 
perturbation typique au-dessus des Front Range, le barrage d'air conduit fréquemment à des zones de convergence et à une augmentation des précipitations à l'est des montagnes. Ces méso-fronts se forment juste à l'est du pied de la chaîne, et ils sont sensibles à la nature du courant synoptique d'est à bas niveau. Dans les autres situations à pente amont, la zone de convergence n'apparaît pas comme un méso-front, mais comme une zone moins nette de convergence. Les profils verticaux des sondages associés au blocage en surface révèlent une structure différente de température et de vent. Ces sondages, complétés par les mesures au sol du vent, de l'humidité et des types de cristaux de neige, permettent quelques interprétations physiques sur la production des chutes de neige dans les régions de soulèvement an altitude qui sont en relation avec les surfaces frontales aussi bien qu'avec le soulèvement au sommet de la cuvette d'air froid induit par blocage. La prédominance d'ágrégats en dendrites fortement givrés implique un soulèvement associé à la structure feuilletée verticale dans les deux orages. Les bandes de réflectivité Doppler présentent une corrélation significative avec l'intensité des chutes de neige. Les deux études de cas démontrent que des modèles distincts de blocage et de convergence peuvent se produire dans les perturbations au-dessus des Front Range du Colorado, chacun d'eux conduisant à une distribution particulière des chutes de neige.

\section{INTRODUCTION}

Severe winter storms plague the eastern slopes of the Rocky Mountains of Colorado each winter, frequently causing transportation difficulties and other

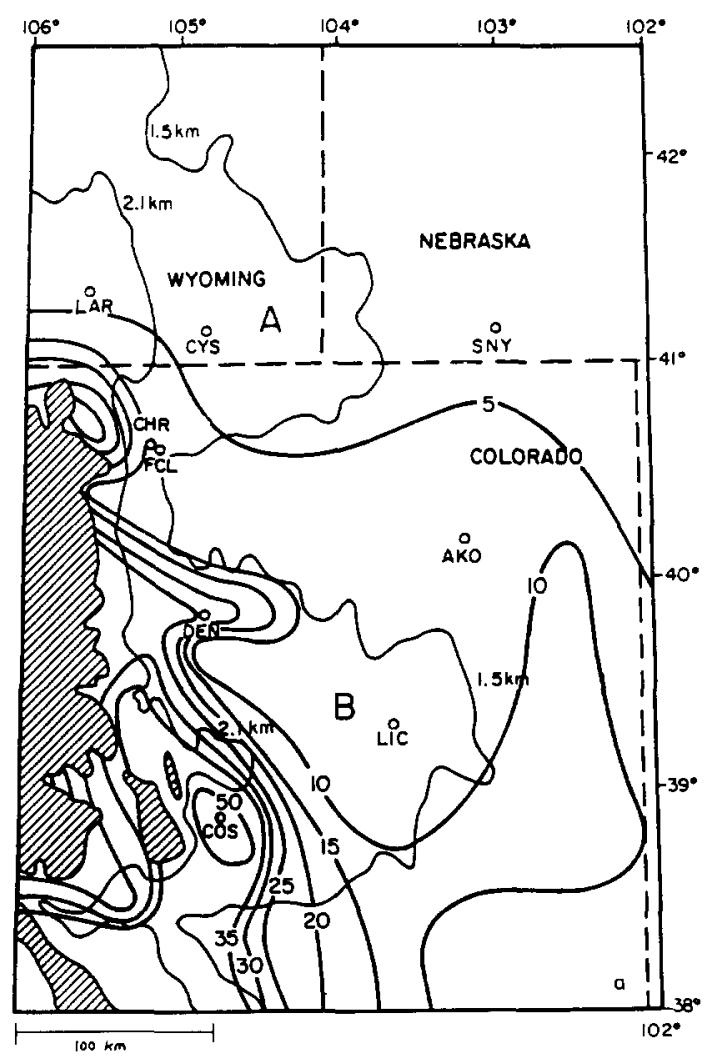



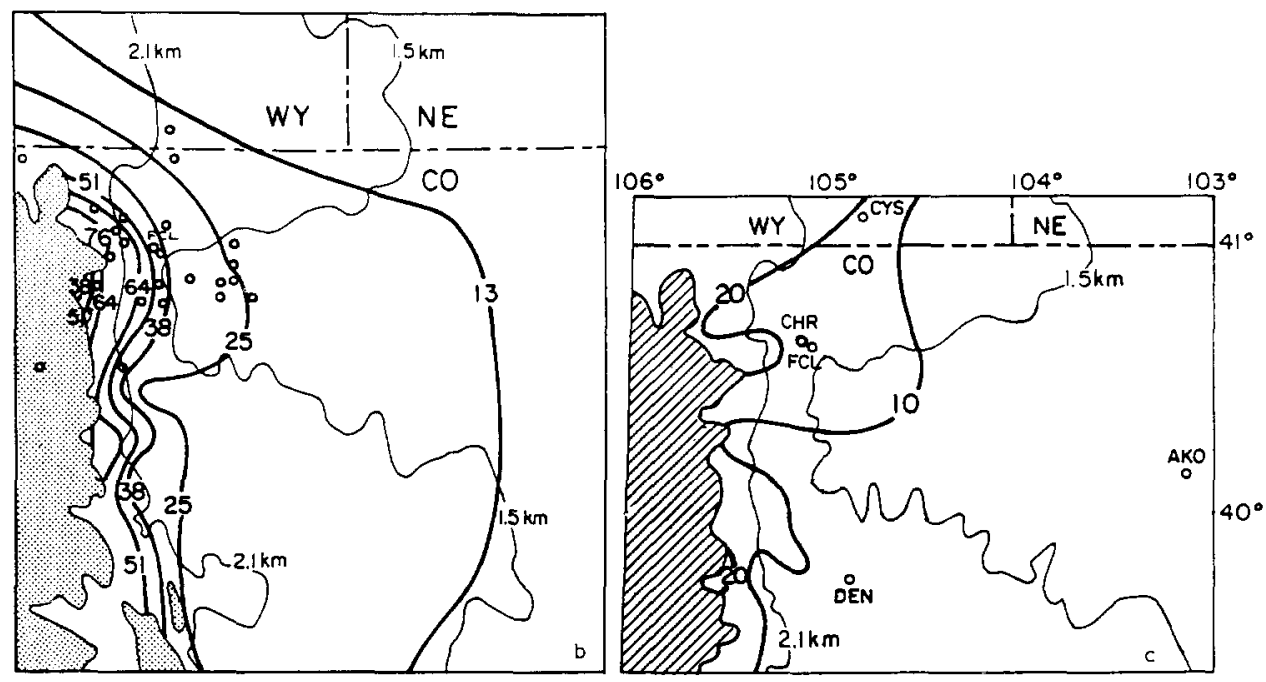

Fig. 1. (a) Topography of the Front Range region, and snowfall for the storm of 14-16 January 1987. Elevation contours $(\mathrm{km})$ are the thin lines. Snowfall contours $(\mathrm{cm})$ are the thick lines. Elevations above $2.7 \mathrm{~km}$ are shaded. Latitude/longitude values are shown on the horizontal top border and vertical border on the right side, respectively. NWS station identifiers are as follows: Laramie ( $L A R)$, Cheyenne (CYS), Sidney $(S N Y)$, Akron $(A K O)$, Fort Collins $(F C L)$, Limon $(L I C)$, Denver $(D E N)$, Colorado Springs (COS), and Christman Field (CHR). State borders are the dotted lines. The capital letters $A$ and $B$ refer to the Cheyenne Ridge and Palmer Divide, respectively. (b) As in (a) for the storm of 30-31 March 1988. Heavy circles correspond to locations of the snowstorm observer network. State abbreviations are as follows: Wyoming $(W Y)$, Nebraska (NE), and Colorado (CO). (c) As in (a) for the storm of 9-10 February 1988.

significant economic losses (e.g., Schlatter et al., 1983). The accurate prediction of these events has encountered serious problems in the past; snowfall distributions, for example, usually exhibit large variability across the region. Fig. 1a presents the topography of the area, along with the snowfall resulting from the 14-6 January 1987 storm. The topography shows several important features along the Front Range, such as the formidable Rocky Mountain barrier located approximately $50 \mathrm{~km}$ to the west. The Cheyenne Ridge and Palmer Divide (labelled A and B, respectively, in Fig. 1a) are east-west ridges on the plains which create $0.6 \mathrm{~km}$ north-south variations in elevation. These topographical features have direct influences on low-level upslope or easterly flow (Toth, 1987), which often develops during the approach and passage of a synoptic-scale disturbance from the west or southwest.

Previous investigations of the physical processes in upslope cloud systems along the east slopes of the Rocky Mountains have shown that both dynamical and microphysical effects must be considered (e.g., Reinking and Boatman, 1986; Wesley et al., 1988). For example, blocking-induced convergent motion and precipitation can occur on sloping plains well east of the foothills (Lilly, 
1981). Schultz et al. (1985) and Dunn (1987) found that the interaction of topography with synoptic-scale upslope can create low-level convergence zones associated with cold air damming. Dunn presented a case study (8-9 December 1985) of a blocking-induced convergence line, or meso-front, oriented approximately north-south which enhanced upward motion in the low levels during a snowstorm. As shown in Fig. 1a, the orientation of the foothills is also approximately north-south from just west of Fort Collins (FCL) to southwest of Denver (DEN). In Dunn's case, an ill-defined cutoff low pressure system aloft developed in the mid-latitude westerlies over the western U.S. The low center aloft, detectable over Nevada, moved into western Colorado as heavy snow fell along the northern portion of the Front Range. Strong surface easterly flow developed over the PROFS (Program for Regional Observing and Forecasting Services; Schultz et al., 1985) mesonetwork. This surface flow was nearly parallel to the isobars east of the mesonetwork. Weak east-southeasterly $700 \mathrm{hPa}$ flow persisted as the system approached eastern Colorado. As the snow intensity increased along the Front Range, easterly surface winds were observed east of the blocking-induced convergence line, while northerly flow was found west of the line. The convergence line apparently formed as a result of low-level easterly flow meeting and ascending a cold air mass located next to the foothills.

Dunn points out that this process is important for "postfrontal anticyclonic upslope flow with no significant surface cyclogenesis" to the south. The quasistationary N-S convergence line formed in-place and had characteristics similar to coastal fronts on the U.S. east coast, which mark the eastern edge of overrunning (see, e.g., Bosart, 1975). In Dunn's case, colder air (by $3-4^{\circ} \mathrm{C}$ ) was located in the region of heavy snowfall to the west of the convergence line.

Lilly (1981) presented Doppler radar and mesonetwork observations of an upslope snowstorm over the Front Range on 9-10 February 1981. This storm, similar to the February case study in this paper, involved the invasion of a lowlevel arctic air mass as heavy snow fell over portions of the Front Range, with blocking-induced convergence and precipitation upstream over the adjacent plains. Significant entrainment through the inversion at the top of the arctic air characterized the dynamics of the storm. The Doppler radar radial velocity field revealed small (on the scale of a few $\mathrm{km}$ ) elongated regions of enhanced velocity both near the surface and aloft. The zone of westerlies aloft apparently served as an important source of precipitation particles.

The SCPP (Sierra Cooperative Pilot Project) emphasized recent observational and modeling efforts in orographic clouds over the Sierra Nevada range in California. Though these storms exhibit many contrasts to those discussed in this paper, the findings of Heggli and Rauber (1988) have direct implications to Colorado upslope systems. For example, blocking and cold air damming can be critical in some of the SCPP storms; the resulting barrier jet (Parish, 1982) exerts an important dynamical (and thus microphysical) effect on Sierra orographic precipitation distributions. Analogous barrier jets occur to a 
somewhat lesser extent along the Colorado Front Range, in the form of a northerly jet rather than a southerly jet. Frequently, the jet can extend nearly to the ground along the Front Range east of the foothills. Such a situation can greatly influence the resulting microphysics and snowfall distributions.

An observer network focusing on Colorado Front Range snowstorms during the winters of 1986-87 and 1987-88 has provided sufficient data for an investigation of terrain blocking along the Front Range and its effect on mesoscale snowfall distributions. Analyses of the 30-31 March 1988 snowstorm using various surface, sounding and radar data indicate that damming of upslope flow led to a localized region of heavy snowfall ( $>80 \mathrm{~cm}$; see Fig. 1b). Another case study in the same geographical area, the 9-10 February 1988 storm (Fig. 1c), also exhibited blocking, but had distinctly different vertical wind and temperature profiles, and no development of a blocking-induced convergence line.

This paper first describes the data sources and then presents evidence for the damming phenomenon and its role in heavy snow production. Subsequent material pertains to the discussion of a heavy snow situation with much less distinct upstream blocking, and interactions between damming and the cloud microphysical structure. Observations of bands on Doppler radar are presented and related to observed snowfall intensity. The implications of these findings to Colorado wintertime forecasting are then discussed.

\section{DATA SOURCES}

Surface observations at the PROFS mesonetwork locations as well as standard National Weather Service (NWS) reporting stations provide wind, temperature, dew point, pressure and precipitation data at specified time intervals (5 min for PROFS and hourly for NWS). Radial velocity and reflectivity, via PPI (plan-position indicator) scans at two angles, $0.2^{\circ}$ and $0.7^{\circ}$, were supplied by operation of the CP-2 single Doppler radar just southeast of Boulder, Colorado. These data were conveniently displayed and looped in real-time on the SERS (Storm Education and Research System) facility at Colorado State University.

Special CLASS (Cross-chain Loran Atmospheric Sounding System) balloon releases just northwest of Fort Collins, Colorado at Christman Field (CHR) provided vertical profiles of wind, temperature and moisture at 2 to 3 $\mathrm{h}$ intervals during the storms. These soundings contained high resolution data (approximately $50 \mathrm{~m}$ in the vertical). The temporal storm evolution can be monitored closely with this equipment. Sounding data of limited resolution were obtained from the standard NWS balloon releases from Denver (DEN) at 12-h intervals, as well as wind profilers at Stapleton airport (DEN in Fig. 1a) and Platteville, approximately $30 \mathrm{~km}$ north of DEN.

A snow crystal observer network was an integral part of the program. Approximately 30 trained volunteer observers (Fig. 1b), centered on the FCL 
area, voluntarily reported crystal types and snow accumulation, as well as standard meteorological measurements critical to storm analyses, such as snow intensity, temperature and wind direction and speed. These measurements were taken at various time intervals, some as often as one-half hourly. The snow crystal types yield important information concerning the cloud microphysical structure. Each observer, equipped with special snow crystal measuring instruments, assessed crystal type (eg., dendritic, platelike, graupel, etc.), crystal size, and degree of riming and aggregation during the periods of significant snowfall at that location. These reports were then analyzed for each storm to give a spatial and temporal picture of the snowfall evolution.

\section{EVIDENCE OF BLOCKING}

\subsection{0-31 March 1988}

The storm of 30-31 March 1988 along the Front Range, which deposited approximately $60 \mathrm{~cm}(2 \mathrm{ft}$ ) of snow in the northern portion (Fig. 1b), produced a similar upslope pattern to the 8-9 December 1985 situation reported by Dunn (1987). Note the extension of heavy snowfall onto the plains just east of the foothills near the FCL area. On the synoptic scale, at 1200 UTC $30 \mathrm{March}$, an amplifying shortwave, evident on the $500 \mathrm{hPa}$ Nested Grid Model (of the National Meteorological Center (NMC)) analysis and centered over east-central Nevada, promised a snowstorm for the Colorado east slope. By 0000 UTC 31

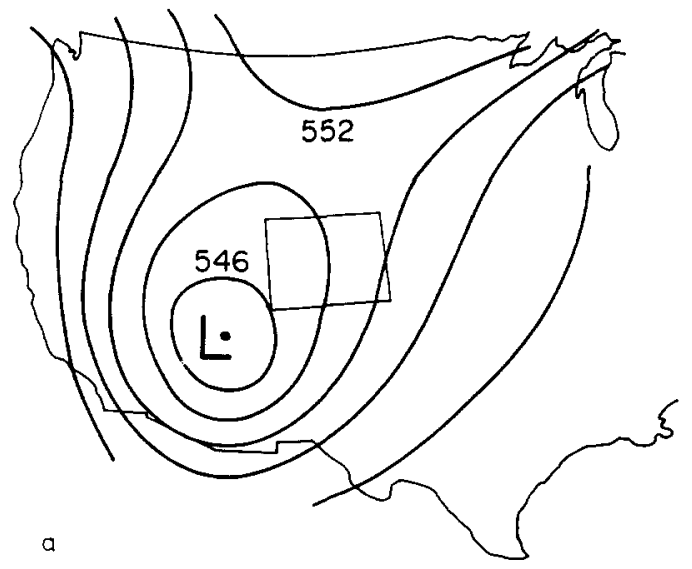

Fig. 2. (a) National Meteorological Center (NMC) height analysis for the $500 \mathrm{hPa}$ surface at 1200 UTC 31 March 1988. Heights are in dm. The state border of Colorado is outlined. (b) As in (a) for the $700 \mathrm{hPa}$ surface. (c) As in (a) for the $850 \mathrm{hPa}$ surface. (d) NMC mean-sea level pressure $(\mathrm{hPa})$ analysis for 1200 UTC 31 March 1988 . Heavy dashed line is a convergence line (see text). 

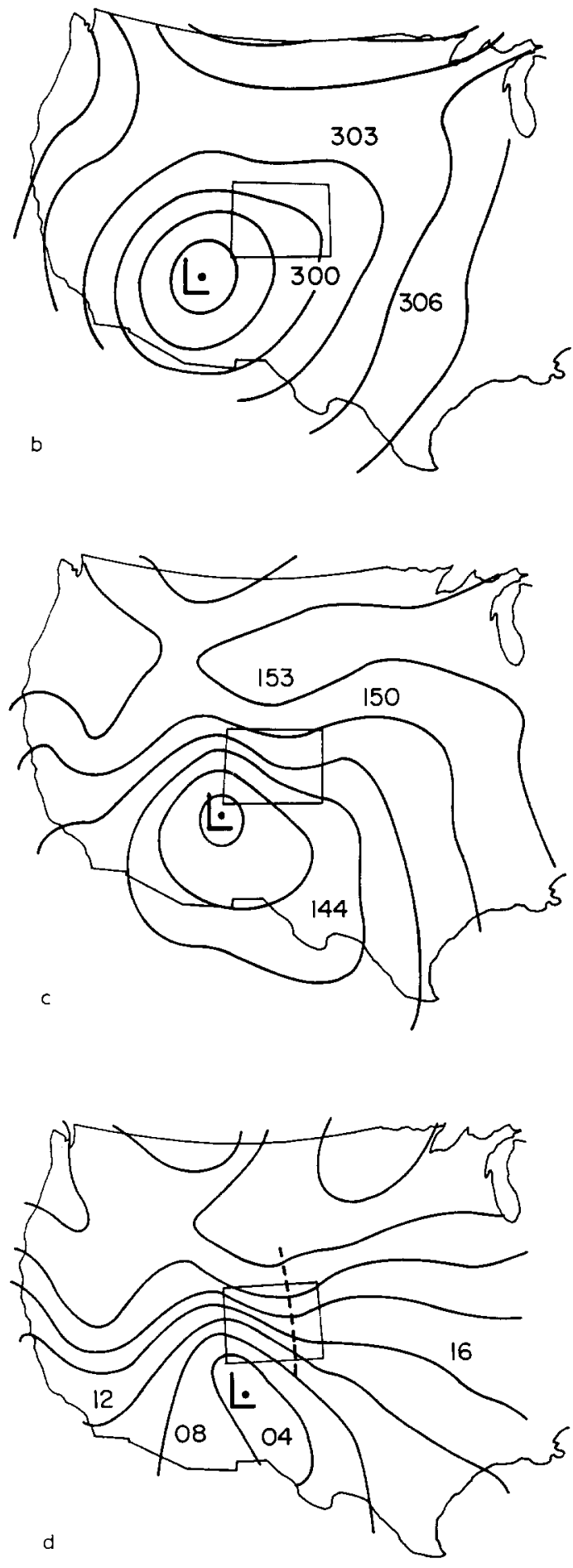

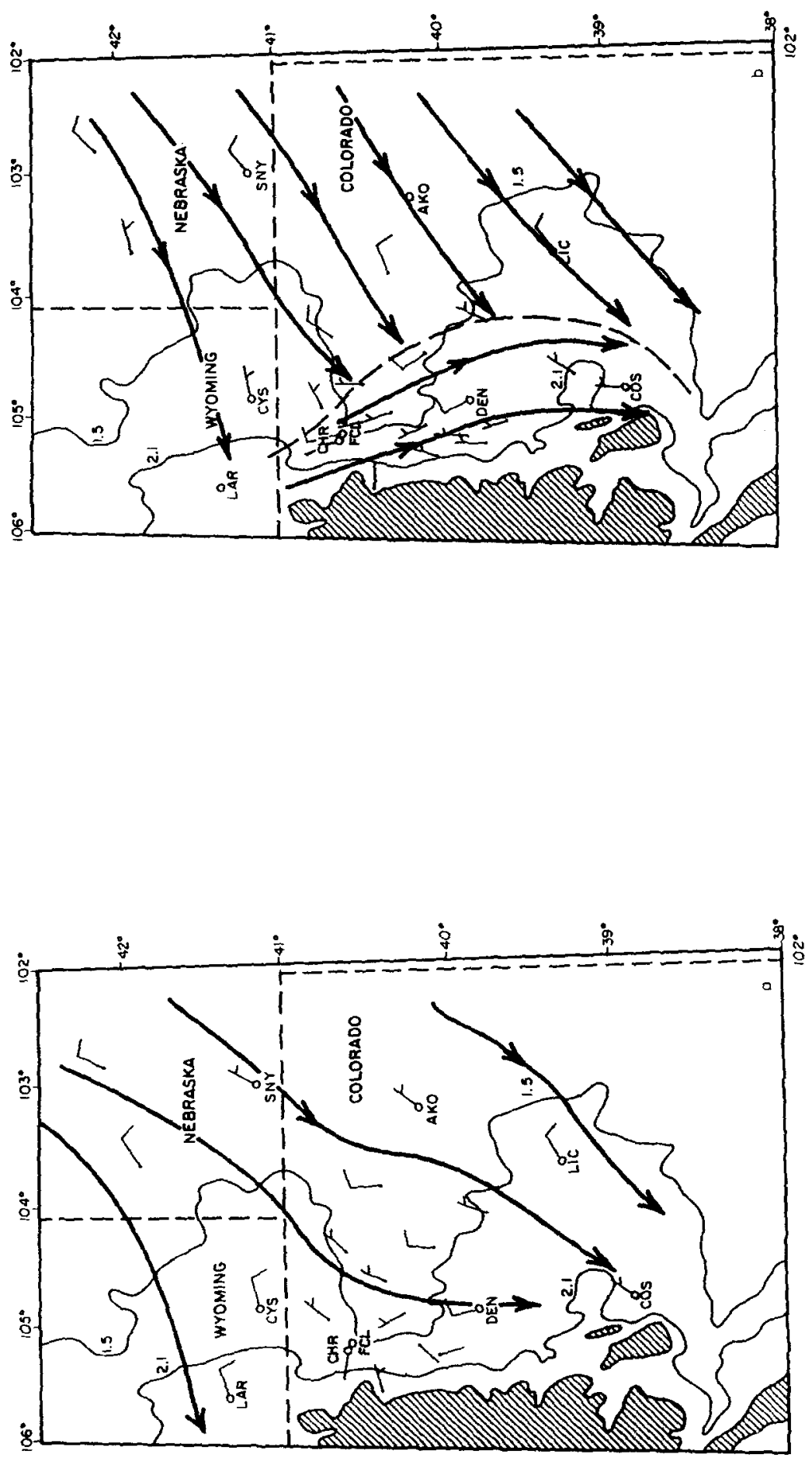

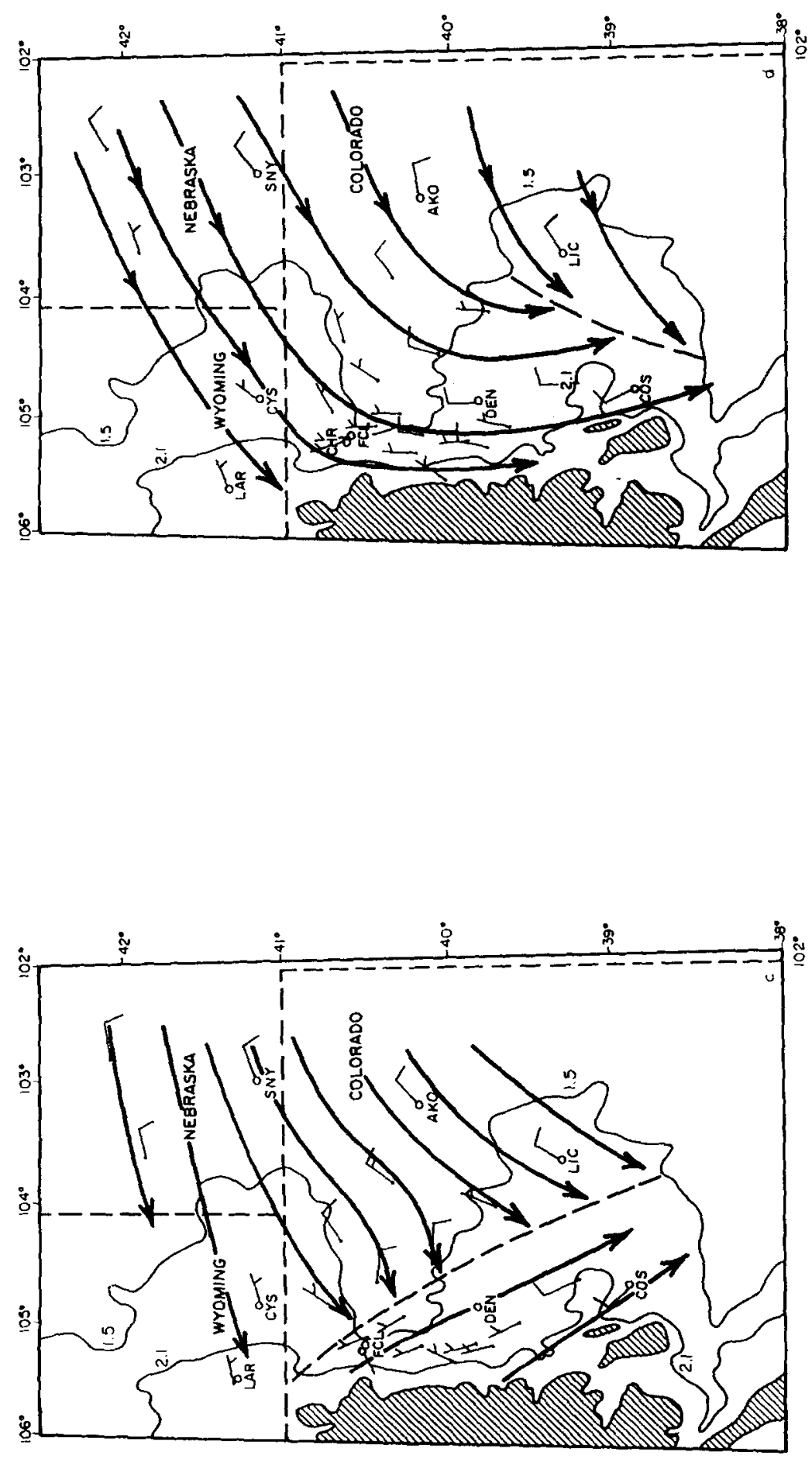

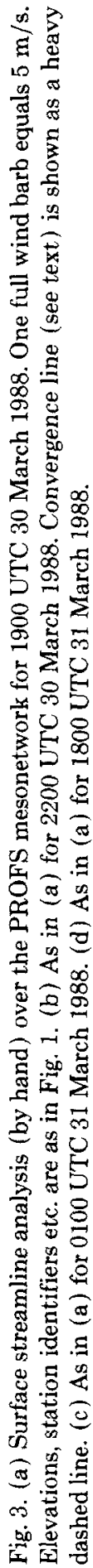


D.A. WESLEY AND R.A. PIELKE
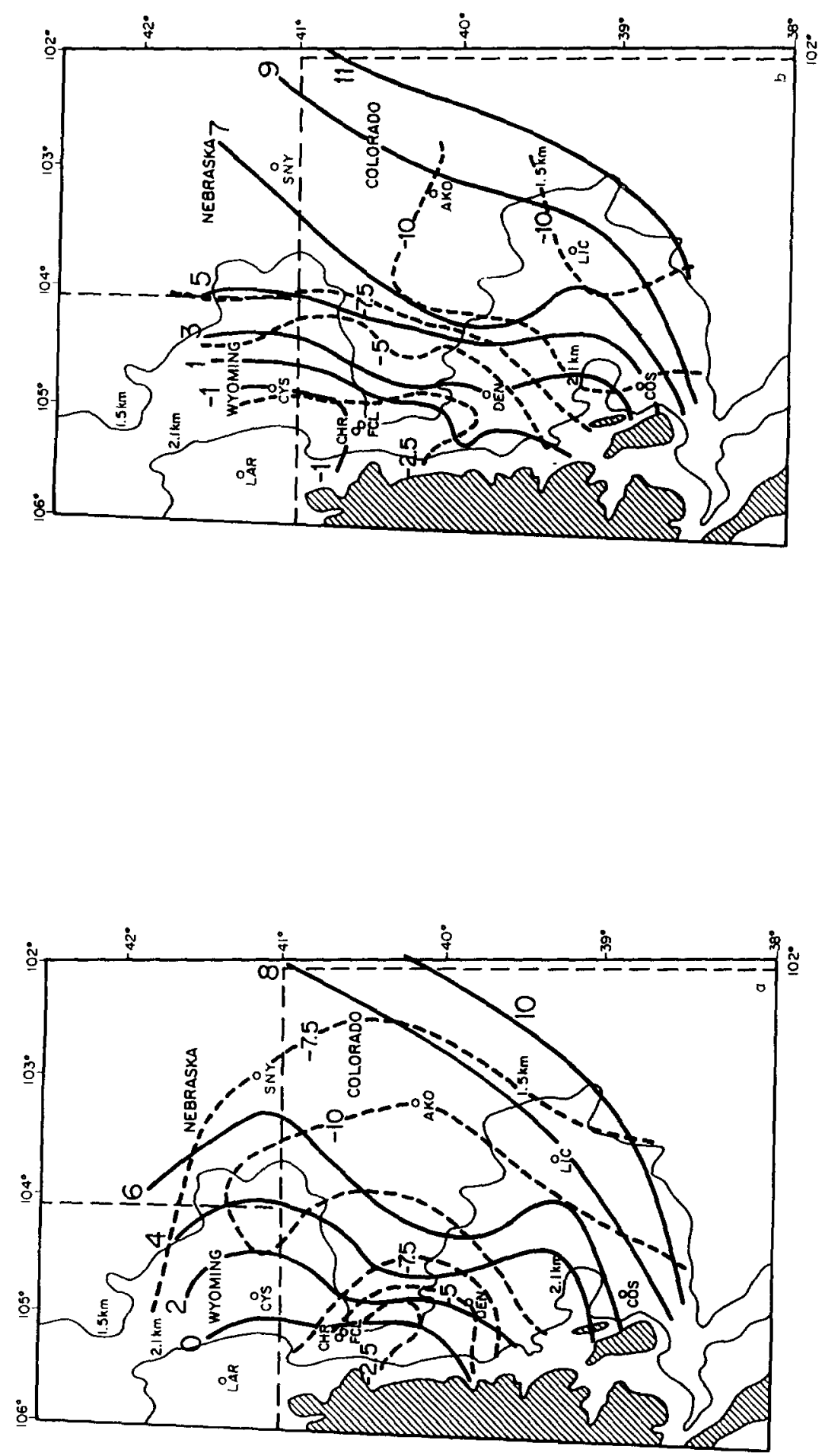


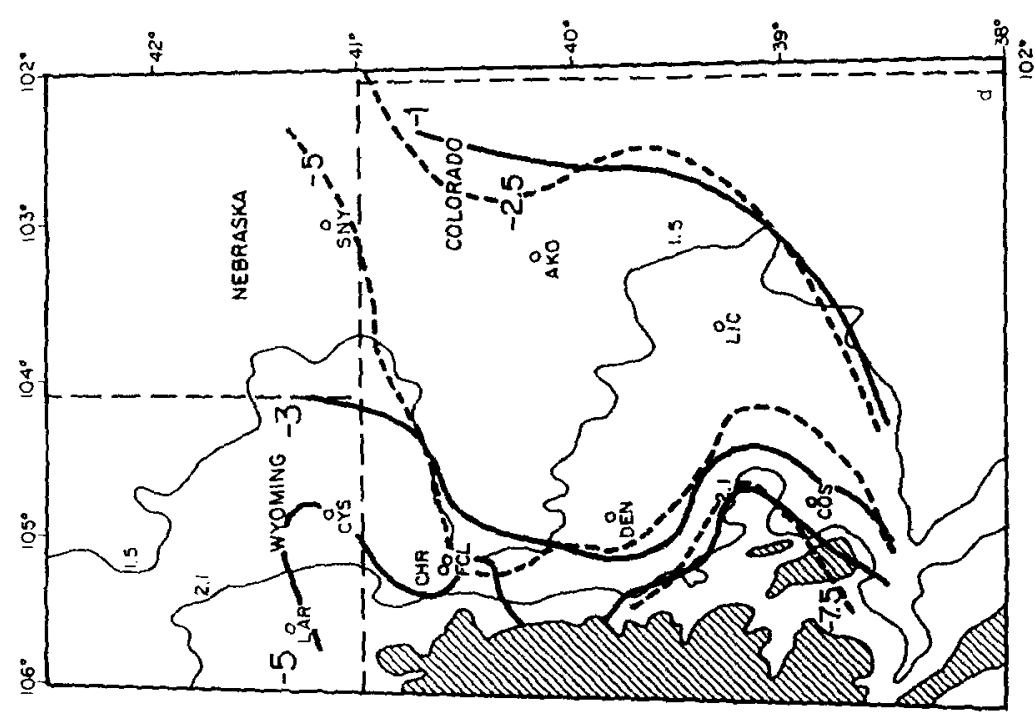

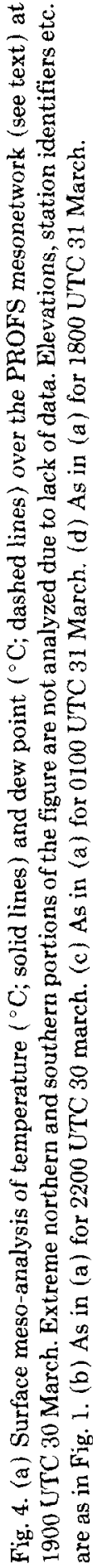

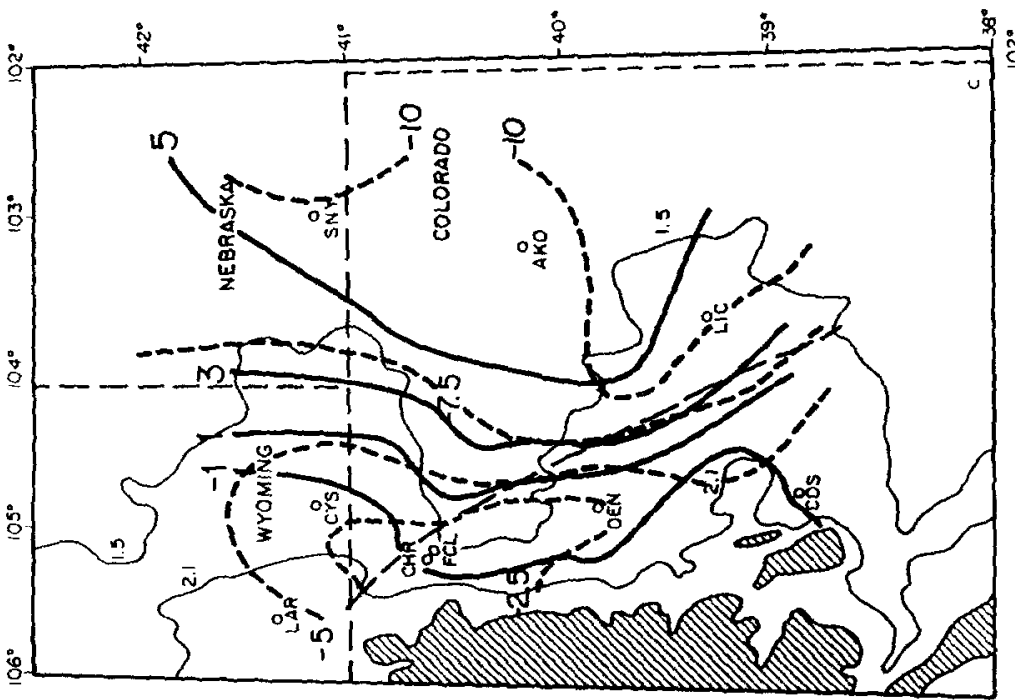


March, snowfall was increasing in intensity in the northern portion of the Front Range. At this time, the $700 \mathrm{hPa}$ analysis revealed a cutoff low just north of the Four Corners region; the surface low pressure, centered in central New Mexico, was pumping warm, moist air into Colorado from the southeast. Winds were easterly at the surface in northeastern Colorado (and approximately parallel to the isobars east of the Front Range). At 1200 UTC 31 March (see Fig. 2 ), when snowfall at FCL was heaviest, the $500 \mathrm{hPa}$ analysis indicated a strong, negatively tilted cutoff low over north-central Arizona, with weak positive vorticity advection in northeastern Colorado. The corresponding $700 \mathrm{hPa}$ low center was located just to the east (Fig. 2b), with east-southeasterly, moist flow over the area of interest. The $850 \mathrm{hPa}$ analysis (Fig. 2c), indicated a strong low just south of the Four Corners, with very strong easterly flow over northeastern Colorado. A weak wedge or nose of low-level high pressure existed over the Front Range at this time (dotted line in Fig. 2d) according to the meansea level pressure NMC analysis. This ridging is a result of the development of a cold pool of air against the foothills. This cooling creates slightly higher surface pressures along the Front Range than in surrounding regions. Such an anticyclonic feature in the isobars occurred also in Dunn's December 1985 storm.

Fig. 3a-d present the surface streamline analyses for the PROFS mesonetwork during the early stages of the storm (on the evening of 30 March) Figs. $4 a-d$ present the temperature and dew point analyses. The analyses indicate the initiation of a quasi-stationary convergence line due to the inability of the stably stratified, low-level easterly flow to ascend with the terrain. This line developed as a cold pool formed against the foothills. The meso-front is similar to the one analyzed in Dunn (1987; his figs. 13-18). At 0100 UTC 31 March (Fig. $3 \mathrm{c}$ ), the northeasterly flow (speeds approximately $2.5-7.5 \mathrm{~m} / \mathrm{s}$ ) on the plains converged with north-northwesterly flow $(2.5-5.0 \mathrm{~m} / \mathrm{s})$ along a northwest-southeast line indicated by the heavy dashes. This orientation was in some contrast to Dunn's north-south line, and determined to some degree the location of heaviest snowfall (this observation will be discussed in the following section ). Maximum convergence occurred along the northernmost portion of the meso-front (near FCL). Thus the cold pool dammed the northeasterly low-level flow. The presence of colder air to the west of this line was readily apparent (e.g. Fig. 4b), as was a tendency for the line to move southeastward (Fig. 3d) during the latter portion of the storm; both of these characteristics were noted by Dunn. The wind speeds were generally weaker by $2.5-5.0 \mathrm{~m} / \mathrm{s}$ in the present case. The snow intensity measurements are shown in Table 1.

A more detailed look at the vertical structure in this storm is shown in the CHR CLASS soundings. The measured temperature profiles are in Fig. 5, with Figs. 6 and 7 presenting the observed wind and relative humidity profiles for the storm. The vertical profile at 0427 UTC in Fig. 5a was measured during the first few hours of moderate to heavy snowfall in FCL. As shown, three distinct layers of the atmosphere are apparent: (1) a shallow low-level of cool 


\section{TABLE I}

Snowfall intensity and wind observations at CHR for the 30-31 March 1988 storm

\begin{tabular}{llll}
\hline $\begin{array}{l}\text { Time } \\
\text { (UTC) }\end{array}$ & $\begin{array}{l}\text { Snowfall } \\
\text { intensity* }\end{array}$ & $\begin{array}{l}\text { Wind } \\
\text { direction }\end{array}$ & $\begin{array}{l}\text { Wind speed } \\
(\mathrm{m} / \mathrm{s})\end{array}$ \\
\hline 1715 & M & E & 1.5 \\
2300 & L & NNW & 2.5 \\
0130 & M & ENE & 5.0 \\
0200 & H & N & 2.5 \\
0230 & M & N & 5.0 \\
0430 & M & NW & 5.0 \\
0530 & H & NW & 6.5 \\
0600 & H & NE & 5.0 \\
0700 & H & WNW & 5.0 \\
0830 & H & NW & 6.5 \\
0900 & H & NE & 5.0 \\
1330 & H & NW & 6.5 \\
1400 & H & NW & 6.5 \\
1730 & L & NW & 5.0 \\
\hline
\end{tabular}

*Snowfall intensities are based on horizontal visibility $V: \mathrm{H}=$ heavy, $V$ less than $0.6 \mathrm{~km}$; $\mathrm{M}=$ moderate, $V$ greater than $0.6 \mathrm{~km}$ but less than $1.2 \mathrm{~km} ; \mathrm{L}=$ light, $V$ greater than $1.2 \mathrm{~km}$.

air (west of the convergence line shown in Fig. 3c) exhibiting weak northwesterly surface winds (Fig. 6) and stable conditions (approximately $840-810 \mathrm{hPa}$ ); (2) a moist mid-level easterly upslope flow $(810-570 \mathrm{hPa})$ which includes a potentially unstable layer from 810 to $770 \mathrm{hPa}$; and (3) a fairly moist upper layer consisting of strong southerly winds (above $570 \mathrm{hPa}$ ); these represent the synoptic flow around the cutoff low pressure system to the southwest. The first four soundings in this storm, shown in Figs. 5a-b and spanning nine hours, are characterized by this layered structure.

Thus layer 2, dammed by the cold pool, overrides layer 1, creating enhanced vertical motions in a moisture-rich region. Visual observations of cloud base height at 2305 UTC 30 March indicated an approximate value of $1.1 \mathrm{~km}$, or $740 \mathrm{hPa}$, which corresponded with the lower portion of layer 2 at this time, as shown in Fig. 5a. Similarly, layer 3 overrides layer 2. The moist conditions observed in layer 3 indicate a potential seeder mechanism by this region for the lower layers (Jiusto, 1967; Reinking and Boatman, 1986). Importantly, crystals nucleated in layer 3 do not evaporate while descending into lower layers and are able to grow to large (2-4 mm diameter according to surface observations) sizes due to the presence of moist easterly flow from 700 to $650 \mathrm{hPa}$. Temperatures in layer 2 are conducive to dendritic crystal growth; these temperatures, ranging from $-12^{\circ} \mathrm{C}$ to $-16^{\circ} \mathrm{C}$, occurred in relatively strong (10$15 \mathrm{~m} / \mathrm{s}$ ), moist easterly flow. The snowfall distribution for the storm, which does not exclusively correspond to topography (Fig. 1b), indicates that intense 
production and growth of precipitation particles probably occurred as layer 2 ascended over layer 1, before the easterly flow reached the barrier. As shown in Figs. 3b-d, the surface convergence line separates layer 1 from layer 2 and the demarcation between the layers apparently slopes upward to the west, yielding a cold pool approximately $30 \mathrm{hPa}$ deep over CHR. More implications for snowfall are discussed in the next section.

\subsection{9-10 February 1988}

The storm of 9-10 February 1988 exhibited smaller snowfall totals (Fig. 1c) but again there was an extension of heavy snow onto the plains in the northern Front Range region. The city of FCL implemented snow emergency procedures as nearly $20 \mathrm{~cm}$ of snow accumulated. On the synoptic scale, at 0000 UTC 10 February, a weak but amplifying shortwave, evident on the $500 \mathrm{hPa}$ NMC analysis (Fig. 8a) was approaching Colorado from the northwest. This upper air feature is well known to forecasters in the Front Range region to often produce a polar frontal passage and only light postfrontal snowfall, and indeed this was

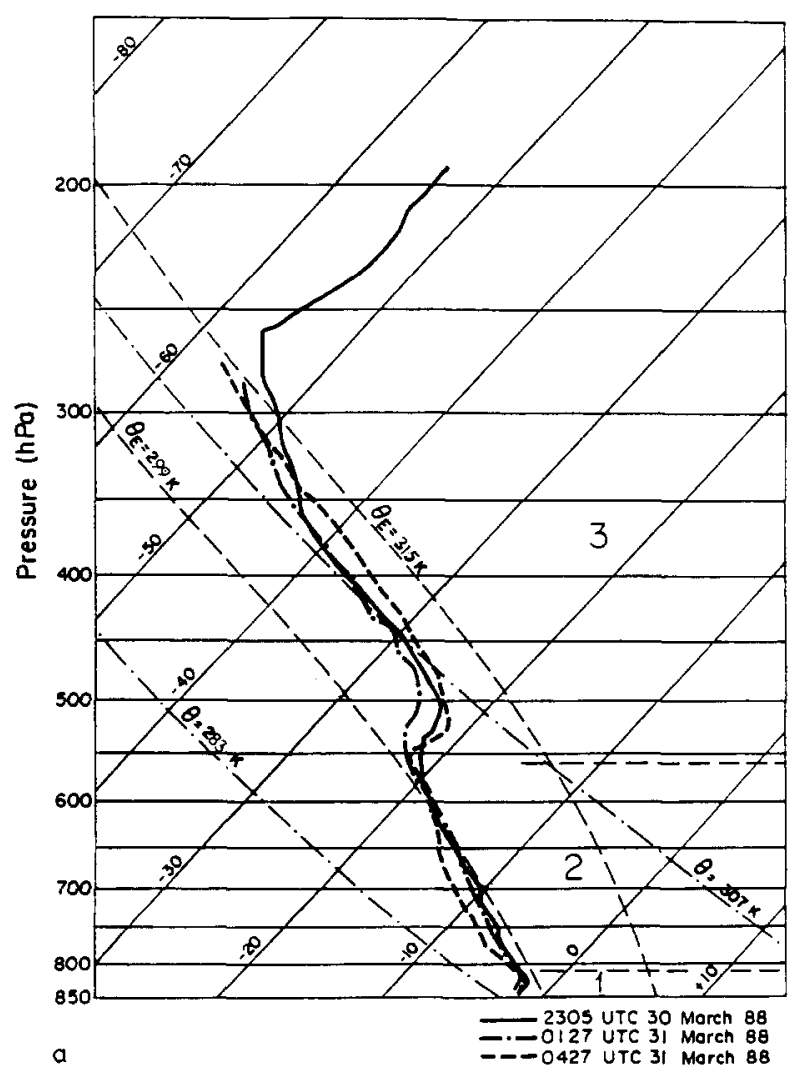




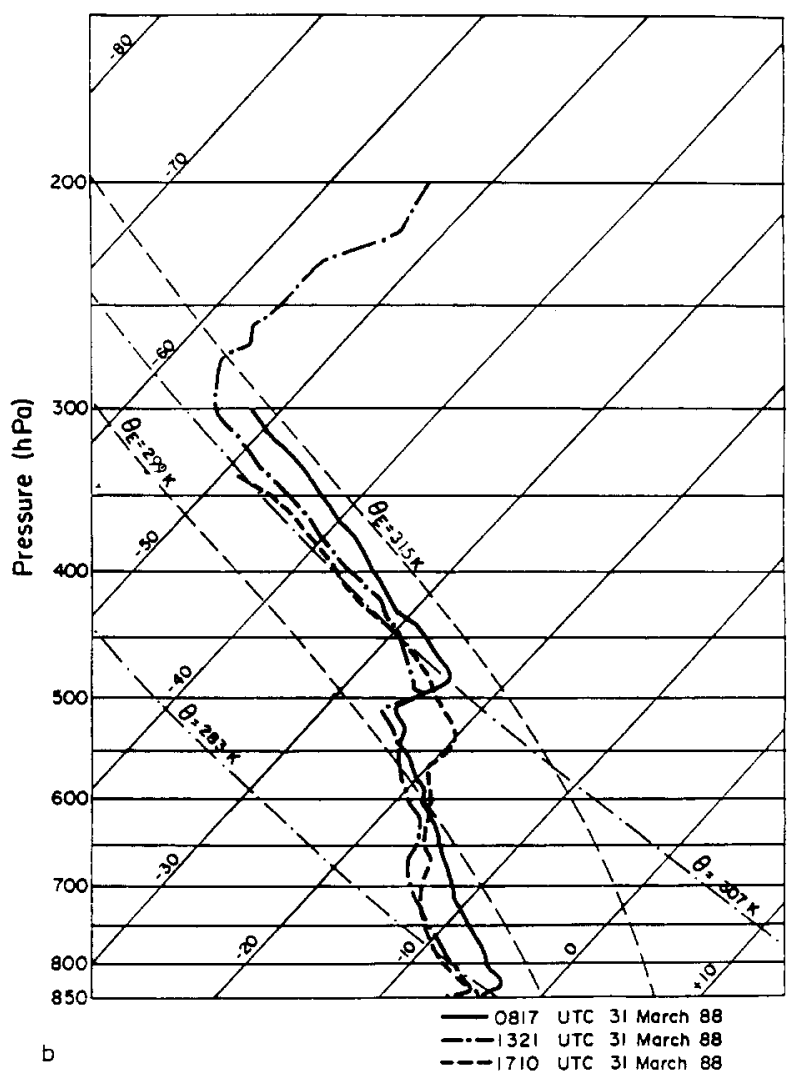

Fig. 5. (a) CLASS temperature profiles for the first three balloon releases at CHR, for the 30-31 March 1988 storm. Horizontal solid lines are pressure $(\mathrm{mb}$ or $\mathrm{hPa})$. Temperature $\left({ }^{\circ} \mathrm{C}\right)$ values are the solid diagonal lines. Two labeled adiabats (dashed-dotted lines) are shown, as well as two moist adiabats (dashed lines). Horizontal dashed lines divide the atmosphere into three layers, denoted 1, 2 and 3 (see text for discussion of the layered structure). (b) As in (a) for the final three CLASS soundings of this storm.

the prediction. Within a few hours, weak frontal passage occurred and snow showers began to fall over the northern portion of the Front Range, similar to the storm documented by Lilly (1981). As the positive vorticity center aloft moved closer, however, snow fell heavily for several hours, especially in and northwest of FCL. At the height of the storm (1200 UTC 10 February; Fig. 8b) weak positive vorticity advection was occurring over the region, similar to the March storm discussed previously. An $80 \mathrm{~m}$ height fall at $500 \mathrm{hPa}$ was recorded overnight at DEN. After the storm subsided, negative vorticity advection characterized the $500 \mathrm{hPa}$ flow (Fig. $8 \mathrm{c}$ ).

As shown in these analyses and the $700 \mathrm{hPa}$ analyses in Fig. 9, upper-level flow remained northwesterly throughout the storm, and no deep upslope developed as in the 30-31 March snow event. At the surface (Fig. 10), a polar 


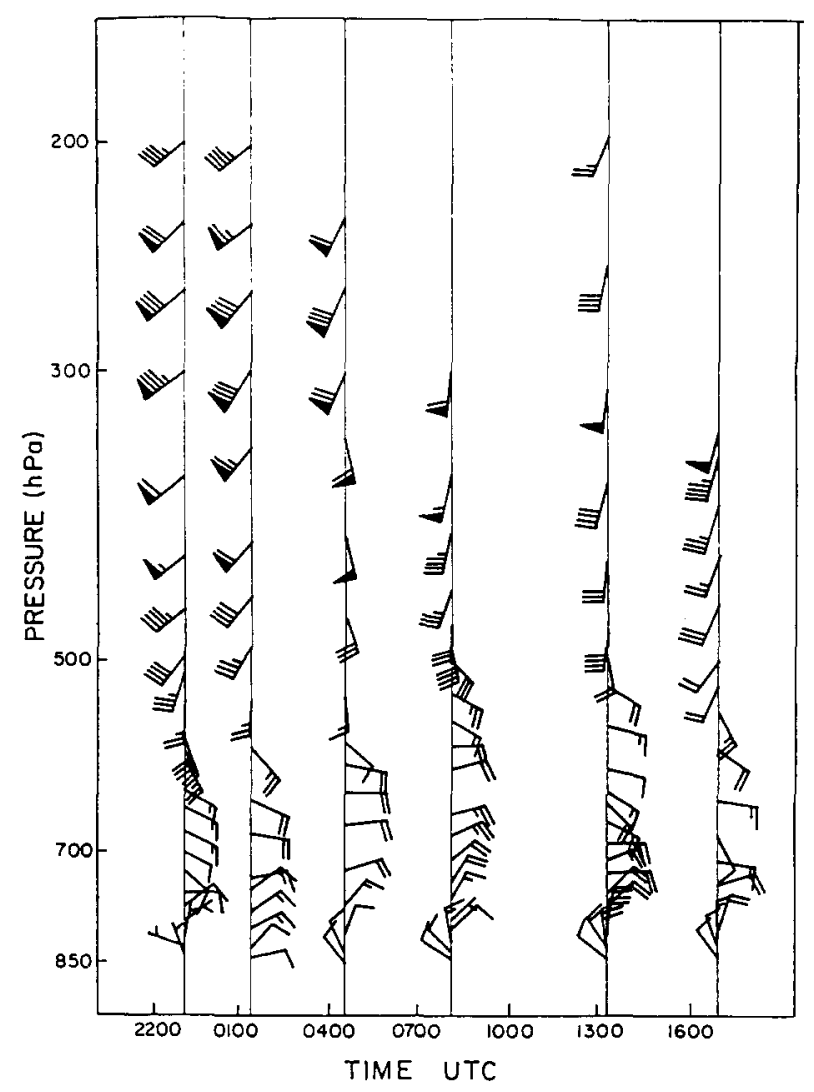

Fig. 6. CLASS wind profiles for the 30-31 March storm. One full wind barb equals $5 \mathrm{~m} / \mathrm{s}$; one flag equals $25 \mathrm{~m} / \mathrm{s}$.

frontal passage accompanied the lowering heights aloft. The gradual intrusion of extremely cold $\left(-18^{\circ} \mathrm{C}\right.$ and below) Canadian air lagged the frontal passage by several hours. A weak cyclone developed by 0000 UTC 10 February just east of DEN, with frigid air moving southward through Wyoming and Nebraska. This pattern is similar to the anticyclonic upslope events discussed by Dunn (1987), and Boatman and Reinking (1984). By 0000 UTC 11 February (Fig. 10d), the polar front had reached Texas. Strong postfrontal southeasterly upslope conditions persisted through the day over the Front Range.

A look at the mesonetwork streamline (Fig. 11), temperature and dew point analyses (Fig. 12) reveals some terrain blocking of upslope flow but no welldefined convergence line as in the two cases previously discussed. A weak cold front had passed through the mesonetwork at about 0300 UTC. At 0600 UTC 10 February (Figs. 11a, 12a), when light snow had just begun to fall at FCL, a relatively warm, moist air mass prevailed along the immediate Front Range. Strong advection of colder, drier air (in an absolute sense) from the northeast 


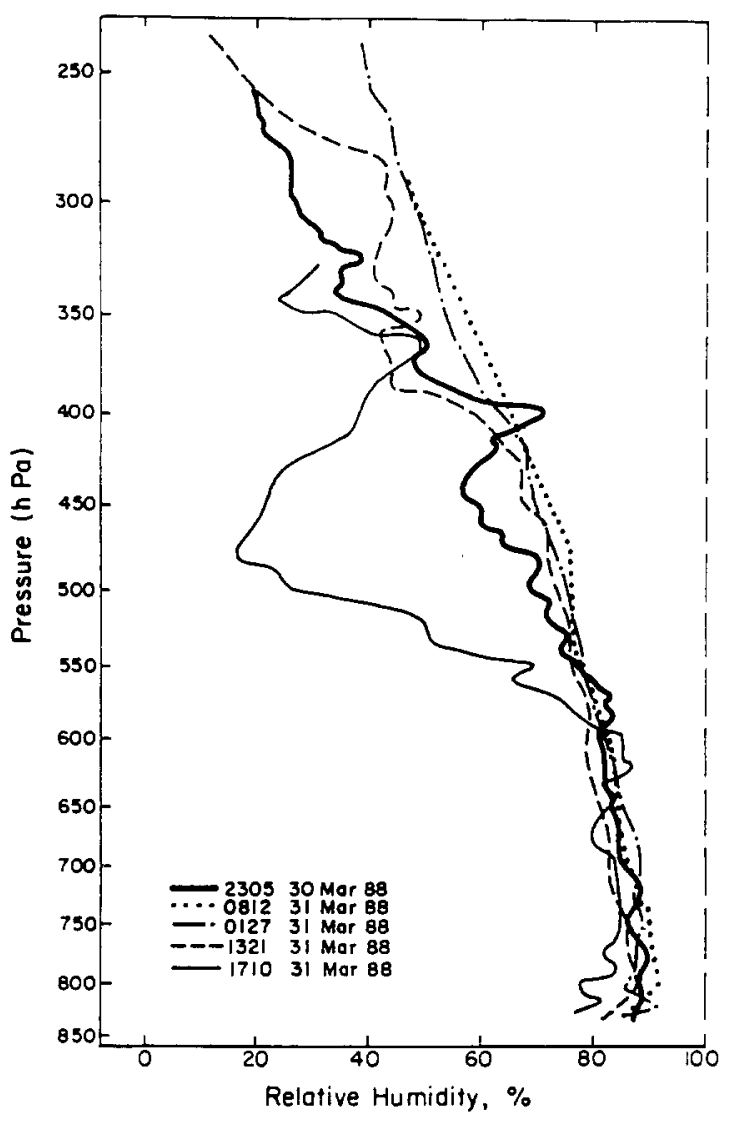

Fig. 7. CLASS relative humidity profiles for the $30-31$ March storm.

was occurring. Light easterly winds dominated the area from DEN to FCL, however, and nearly saturated conditions characterized this weak upslope. A weak wind shift from northeasterly to southeasterly was observed at the CHR ground station at approximately 0645 UTC, as snow intensity was increasing to heavy (Table II). At 0900 UTC (Figs. 11b, 12b), snowfall was heavy in the northern mesonetwork region. Later, during a brief period of easterly wind, snowfall intensity decreased to moderate until another switch to southeasterly flow. However, in contrast to the dammed cold air mass against the foothills in the 30-31 March 1988 case, temperatures nearest the foothills were actually warmer than those of the upstream easterly flow. By 1500 UTC, moderate eastnortheasterly upslope winds were divergent, apparently due to topographic blocking, to the north and south along an east-west line approximately $30 \mathrm{~km}$ south of FCL.

This feature created low-level convergence in the northern and southern portions of the Front Range. The enhanced low-level convergence near and to 

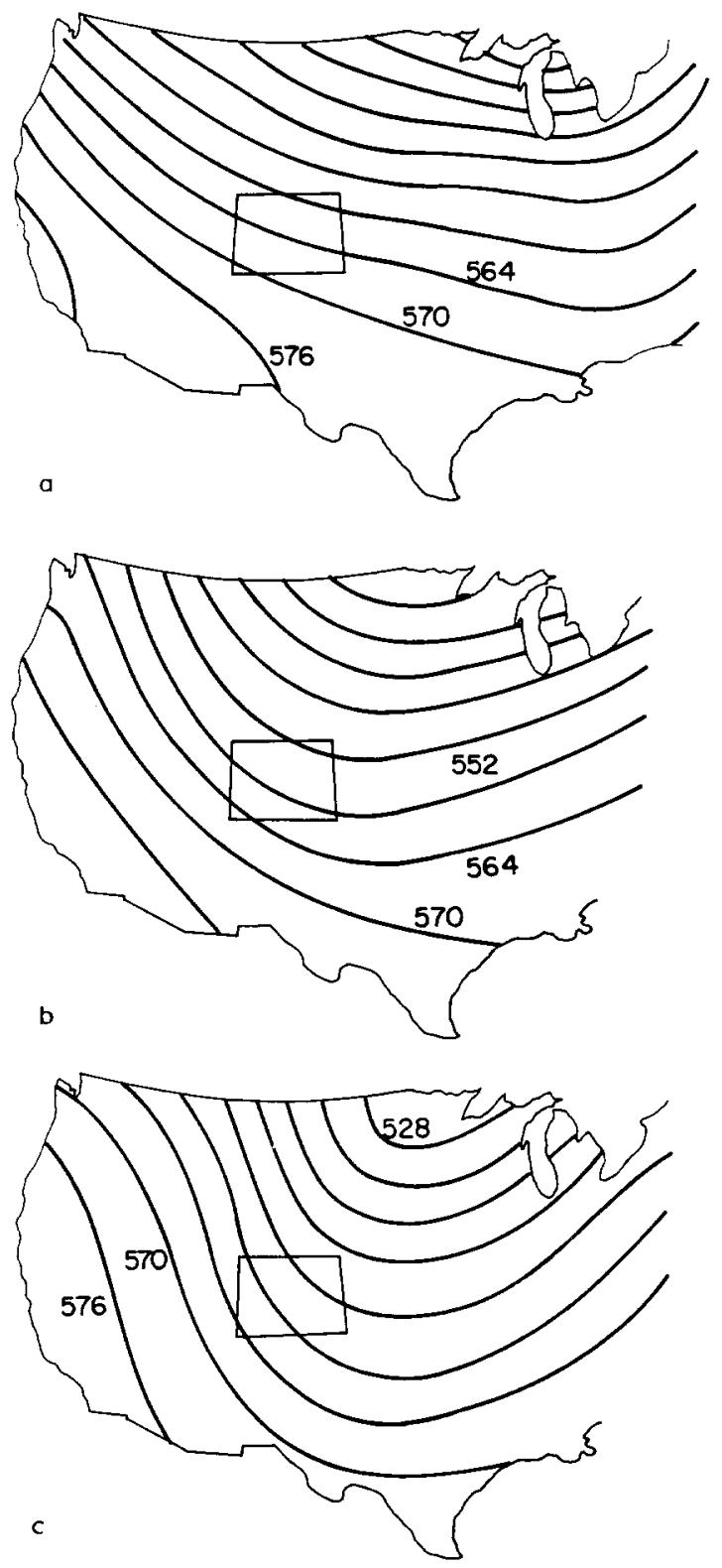

Fig. 8. (a) NMC $500 \mathrm{hPa}$ analysis for 0000 UTC 10 February 1988 . Heights are in dm. (b) As in (a) for 1200 UTC 10 February. (c) As in (a) for 0000 UTC 11 February.

the north of FCL may have contributed to heavy snowfall there from approximately 0630 to 1230 UTC. At CHR, the southeasterly low-level flow developed several hours after postfrontal upslope flow began; similarly, heavy snowfall did not occur until around 0700 UTC. Mesonetwork analyses indicate blocking 

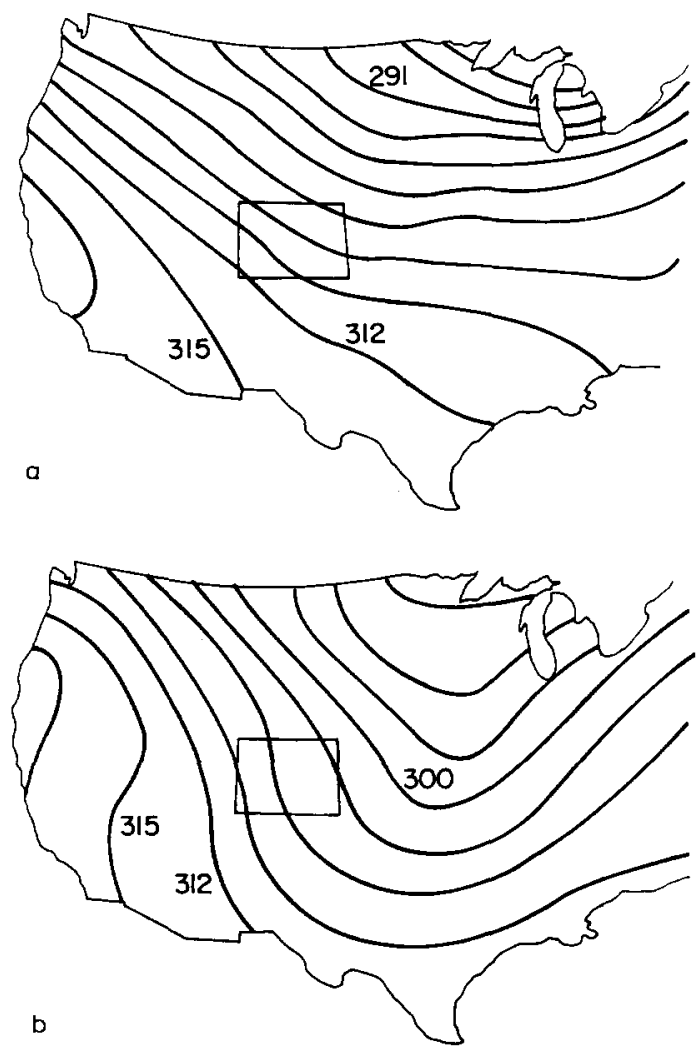

Fig. 9. (a) NMC $700 \mathrm{hPa}$ analysis for 1200 UTC 10 February. (b) NMC $700 \mathrm{hPa}$ analysis for 0000 UTC 11 February.

occurring between approximately 0800 and 1600 UTC, which corresponded fairly well with the period of heaviest snow at CHR. At 1500 UTC (moderate snowfall in FCL at this time; Fig. 11d), the divergence line was readily apparent. In addition, at 1200 and 1500 UTC, the polar front was located southwest of DEN and extended southeastward. Moderate snowfall was falling in COS at 1500 UTC near this cold front.

The CLASS soundings for this storm, shown in Figs 13-15, also revealed a layered structure, but with some significant differences from the March storm. The first sounding (Figs. 13a and 14), released during light snowfall at CHR, indicated two layers, one of northeasterlies and one of westerlies, separated by an inversion centered at approximately $730 \mathrm{hPa}$. By $0812 \mathrm{UTC}$, when snowfall at CHR was heavy, the height of the inversion increased to about $680 \mathrm{hPa}$. After the passage of the arctic front, three distinct layers were apparent $(0957$ UTC ), also during heavy snowfall. The layers were separated at approximately 870 and $690 \mathrm{hPa}$, where significant shear and lapse rate changes occurred. The 

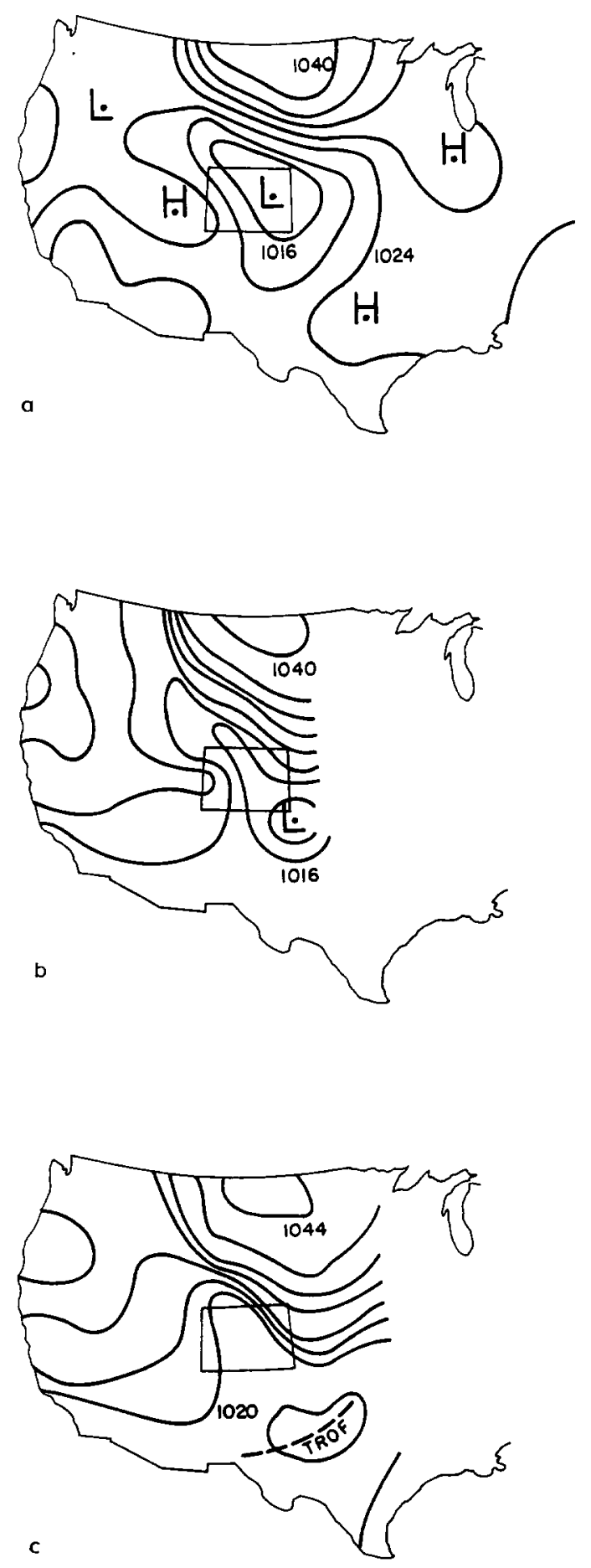


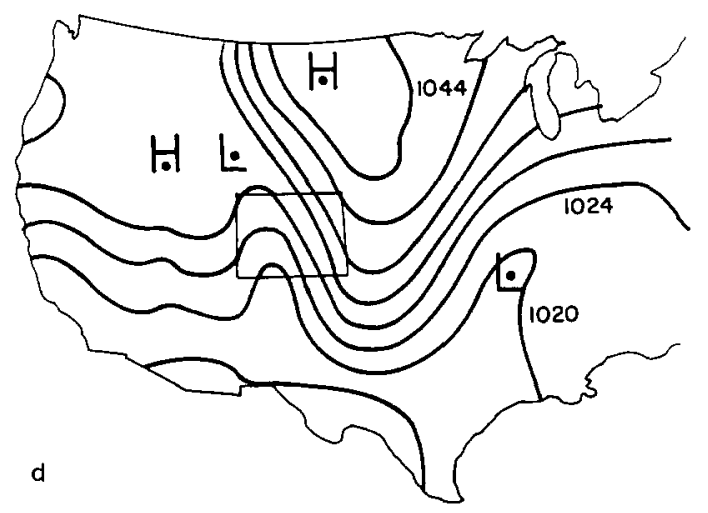

Fig. 10. (a) NMC mean-sea level pressure analysis (hPa) for 0000 UTC 10 February. (b) As in (a) for 0600 UTC 10 February. Data over the midwestern U.S. were missing. (c) As in (a) for 1500 UTC 10 February. (d) As in (a) for 0000 UTC 11 February.

base of the lower inversion, as determined from BAO (Boulder Atmospheric Observatory near Erie, Colorado) and CHR data, varied from 250 to $400 \mathrm{~m}$ above the ground during the storm. The easterly upslope layer was much shallower for the present case than the March storm and winds within the arctic air were southeasterly. At 1314 UTC (Fig. 13b), snowfall had decreased to moderate intensity, and layer separation occurred at approximately 780 and $700 \mathrm{hPa}$. At $1454 \mathrm{UTC}$, cloud base was located within the strong inversion at the top of the arctic air mass. (Lilly, 1981 reported increasing depth of an arctic air mass in the upslope storm of 9-10 February 1981, as well as persistent light easterly winds in the cold air; for the present case, the depth actually decreased by approximately $300 \mathrm{~m}$ between 1314 and 1654 UTC.) The lowest layer had cooled significantly by this time. The 1200 UTC 10 February DEN sounding showed no significant differences from the CHR profiles at 0957 and 1314 UTC aside from the absence of surface SE flow. The inversions appear much less sharp on the reported DEN data, apparently due to the greatly reduced vertical resolution.

\subsection{Differences between the two cases}

Thus, the observed differences between the two storms are as follows.

(1) For the 30-31 March 1988 storm, a well-defined, quasi-stationary convergence line formed as a result of cold air damming, leading to a snowfall maximum approximately parallel to the line some distance to the west.

(2) The 9-10 February 1988 event did not exhibit a convergence line, but did have topographically-induced convergence which affected the precipitation structure. However, the precipitation pattern was more correlated with topography than in the March case. 

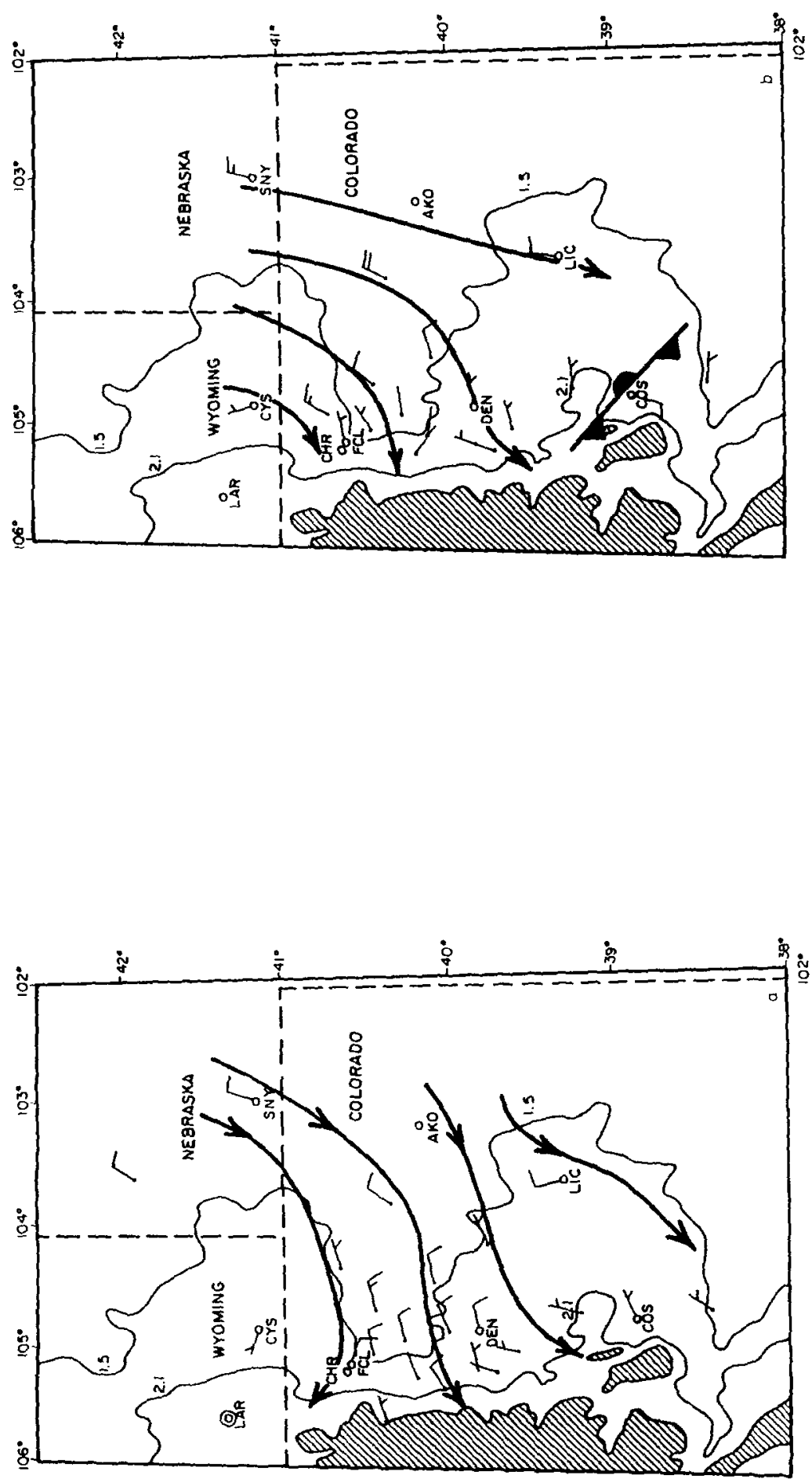


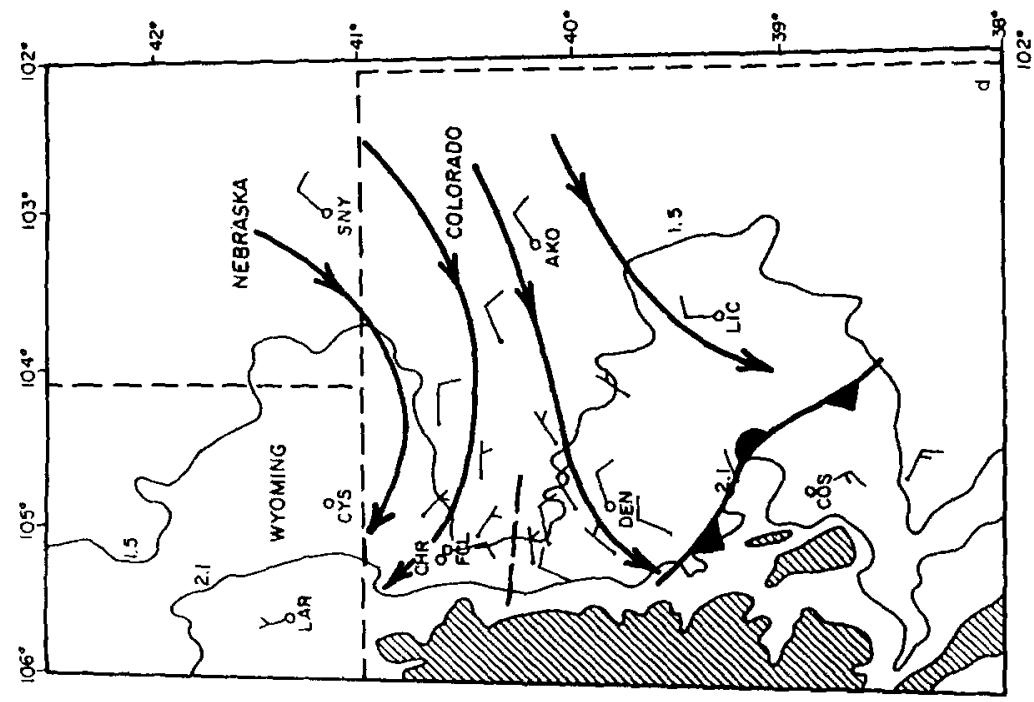

छे $\cong$

is 0 窎

东 5

궁용

은 8

苍密

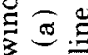

可

里

ธิ

$\infty$

证

当这

$g$.

क :

红

넝

5 o

$8:$

녕

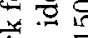

过

跑

蛘

8.0

兄节出

우워

$\infty$

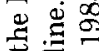

家

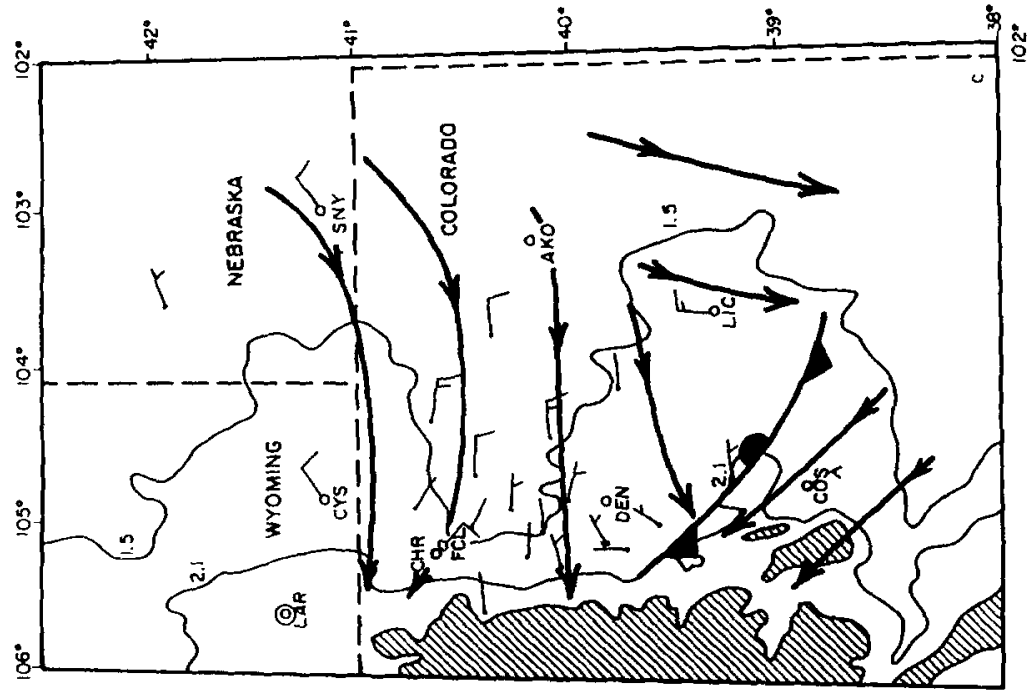

웡

종ㅇ

롱

of

\%

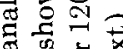

嗼

可

ॠ $₫$

药

过艺 0

:

क

(한

¿ 它胥

造造 

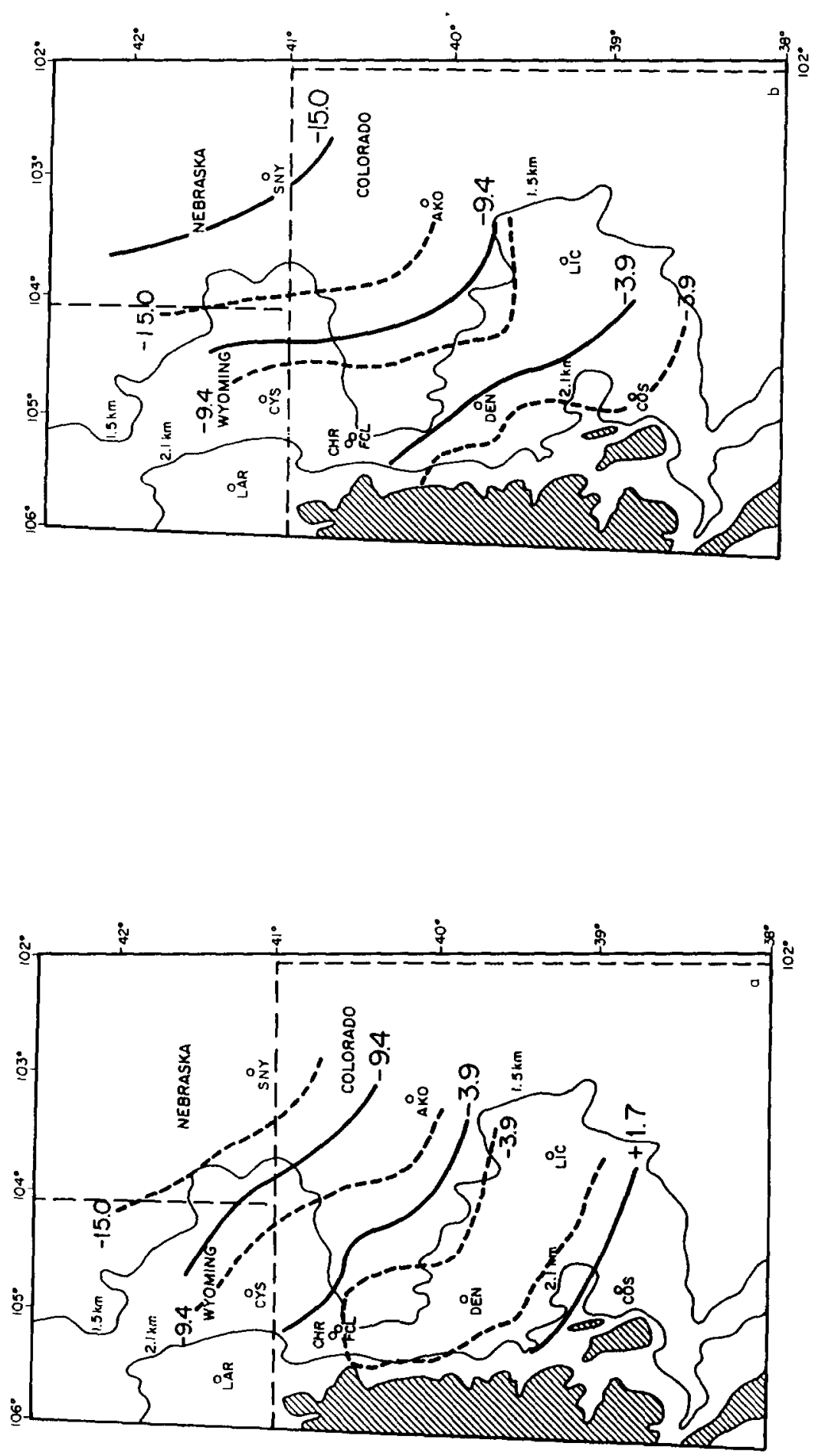


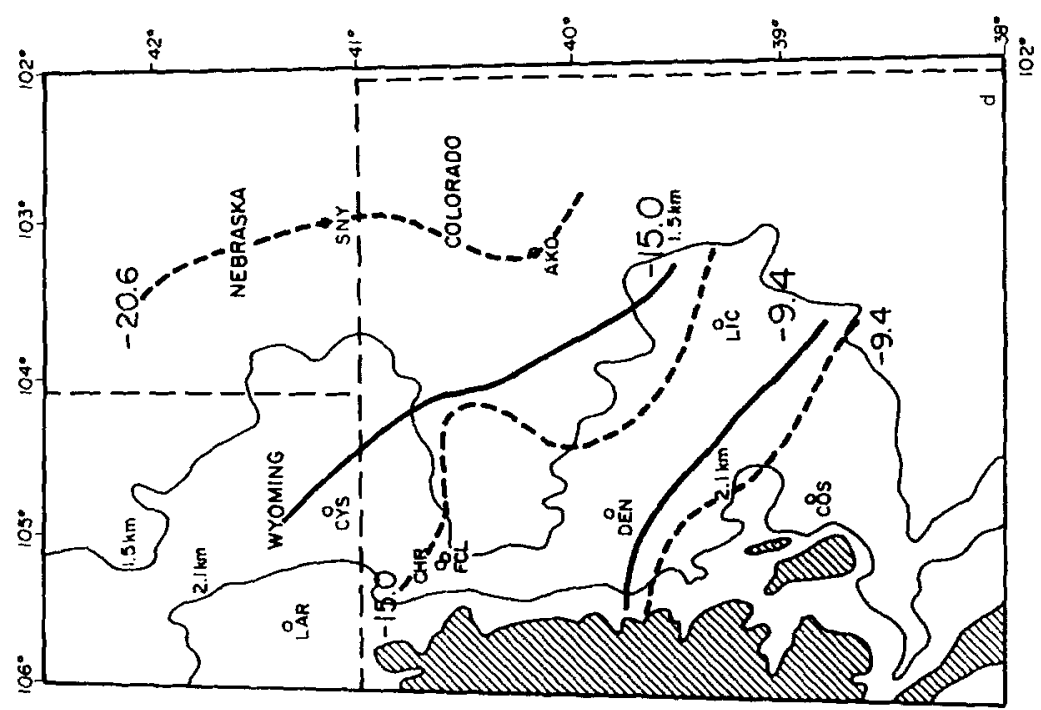

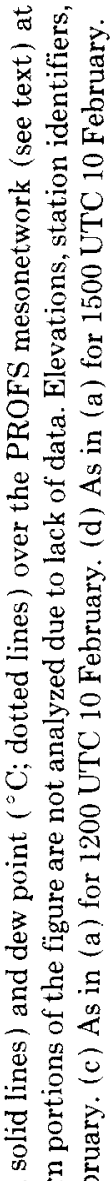

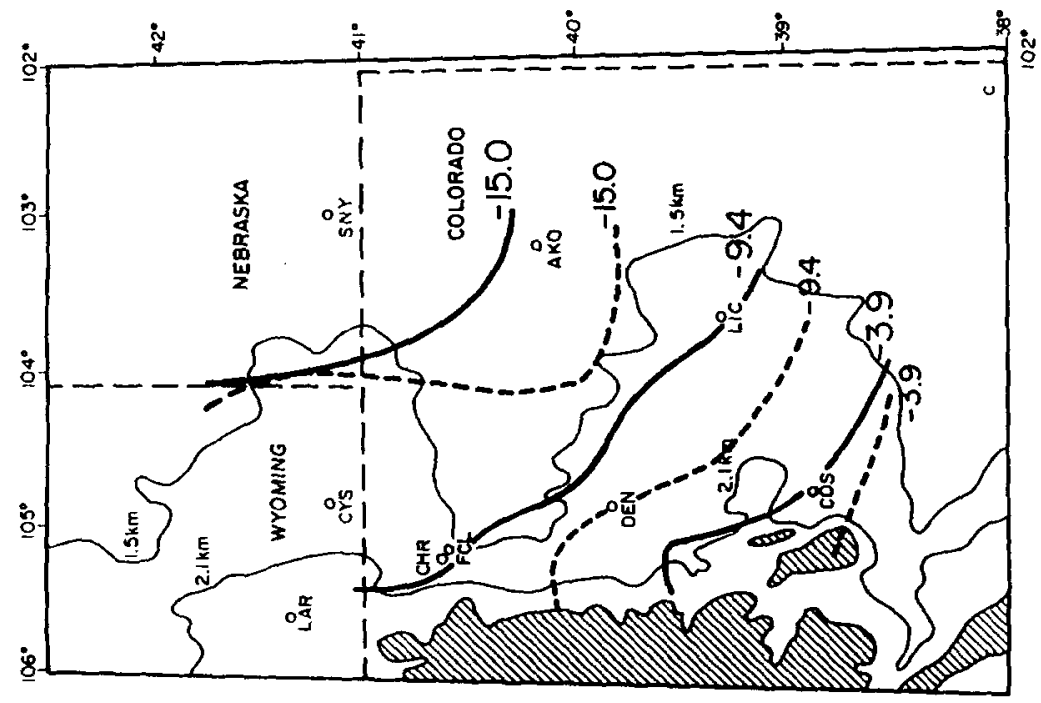

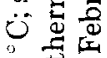

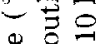

至

ฮี

용

$\Phi$

영

需田

要焉.

要

穿家

\&

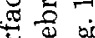

空的

क $ᄋ$

(2) 0

돈

호용 


\section{TABLE II}

Snowfall intensity and wind observations at CHR for the 10 February 1988 storm

\begin{tabular}{llll}
\hline $\begin{array}{l}\text { Time } \\
\text { (UTC) }\end{array}$ & $\begin{array}{l}\text { Snowfall } \\
\text { intensity*1 }\end{array}$ & $\begin{array}{l}\text { Wind } \\
\text { direction }\end{array}$ & $\begin{array}{l}\text { Wind speed } \\
(\mathrm{m} / \mathrm{s})\end{array}$ \\
\hline 0600 & L & ENE & 2.5 \\
0630 & M & ENE & 2.5 \\
0700 & H & SE & 1.5 \\
0730 & H & S & 1.5 \\
0800 & H & SE & 2.5 \\
0830 & M & E & 2.5 \\
0900 & M & SE & 5.0 \\
0930 & H & SE & 3.5 \\
1000 & H & SSE & 4.5 \\
1030 & H & SE & 4.5 \\
1100 & M & SE & 5.5 \\
1145 & H & - & - \\
1200 & H & SE & 4.0 \\
1230 & M & SE & 5.0 \\
1300 & M & SE & 5.0 \\
1330 & M & SE & 5.0 \\
1400 & M & SSE & 4.5 \\
1430 & M & S & 3.5 \\
1500 & M & S & 2.5 \\
1530 & L & SSE & 5.0 \\
\hline
\end{tabular}

${ }^{* 1}$ See Table I.

(3) The March storm was a deep, relatively warm upslope pattern with a weak cold pool near the surface and a strong frontal inversion aloft.

(4) The February storm soundings revealed only a shallow, but strong cold pool and a weak frontal inversion aloft. Mid-level easterly components in the winds were müch weaker than those in the March event.

The two types of observed blocking in these storms, topographical blocking and cold air damming, both arise as easterly flow is unable to ascend the sloping terrain and foothills along the Front Range due to stable lapse rates. When the low levels are extremely stable, as in the 10 February case after passage of an arctic front, easterly flow is deflected well upstream of the foothills.

\section{THE ROLE OF MOISTURE CONTENT IN THE UPSLOPE LAYER}

A critical difference exists in the moisture content of the incoming surface easterly flow (inflow) in the 30-31 March 1988 storm when compared to the 8-9 December 1985 storm presented in Dunn (1987). This difference exerts a major influence on the corresponding snowfall distribution. As shown in Figs. $4 \mathrm{~b}$ and $4 \mathrm{c}$, typical inflow surface temperatures and dew points upstream of 


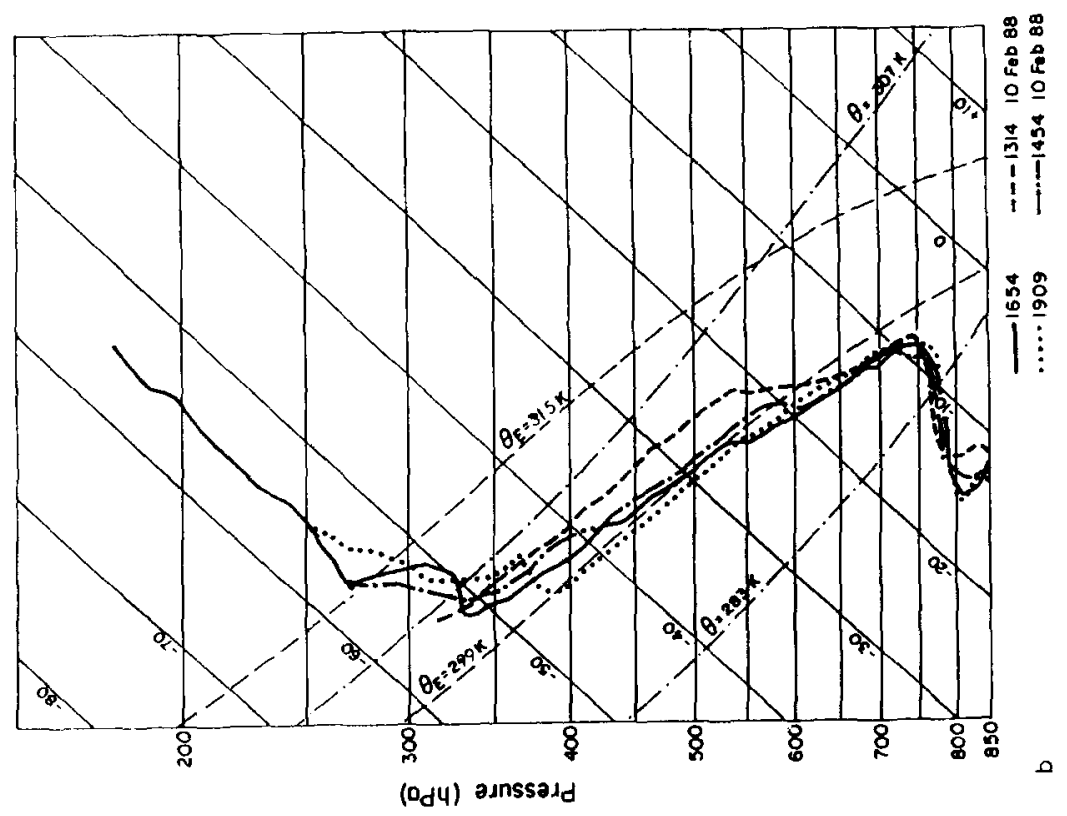

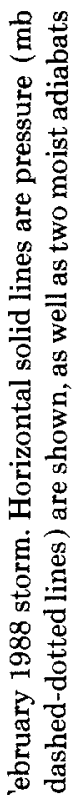

过

온

o

要焉

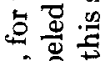

完

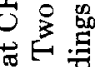

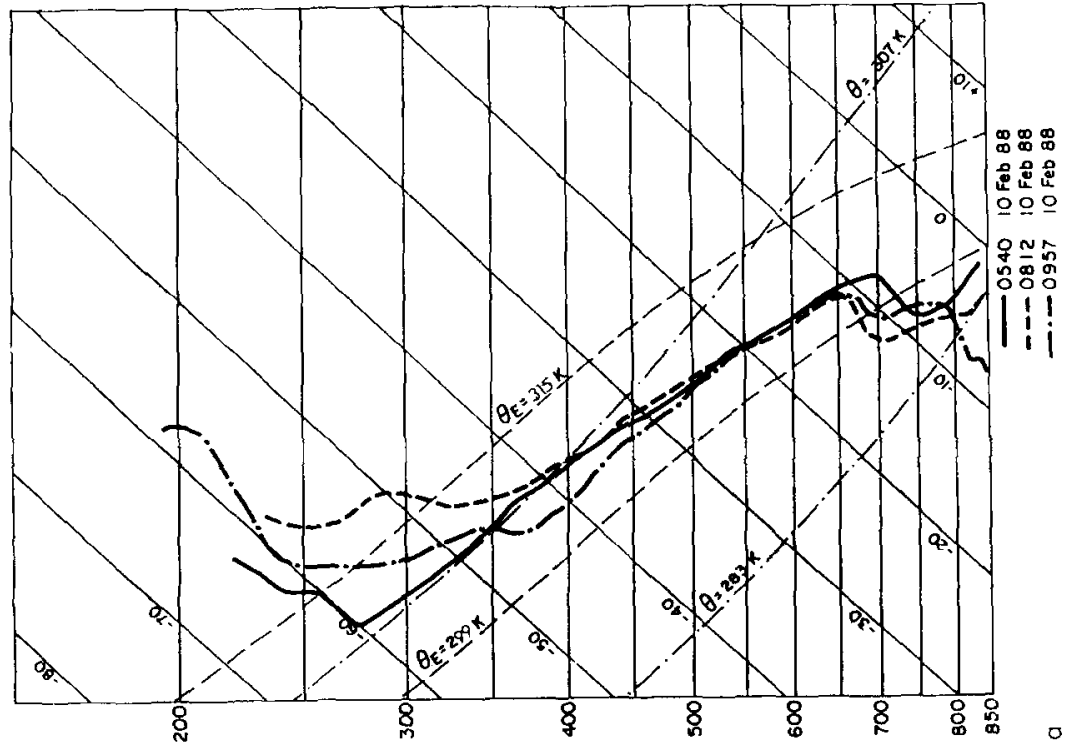

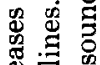

焉

동

空

战总

点焉

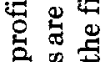

氜苛

帚它

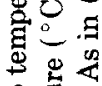

跑泀

它密昆

త્త

ले

(Od4) adnssald 


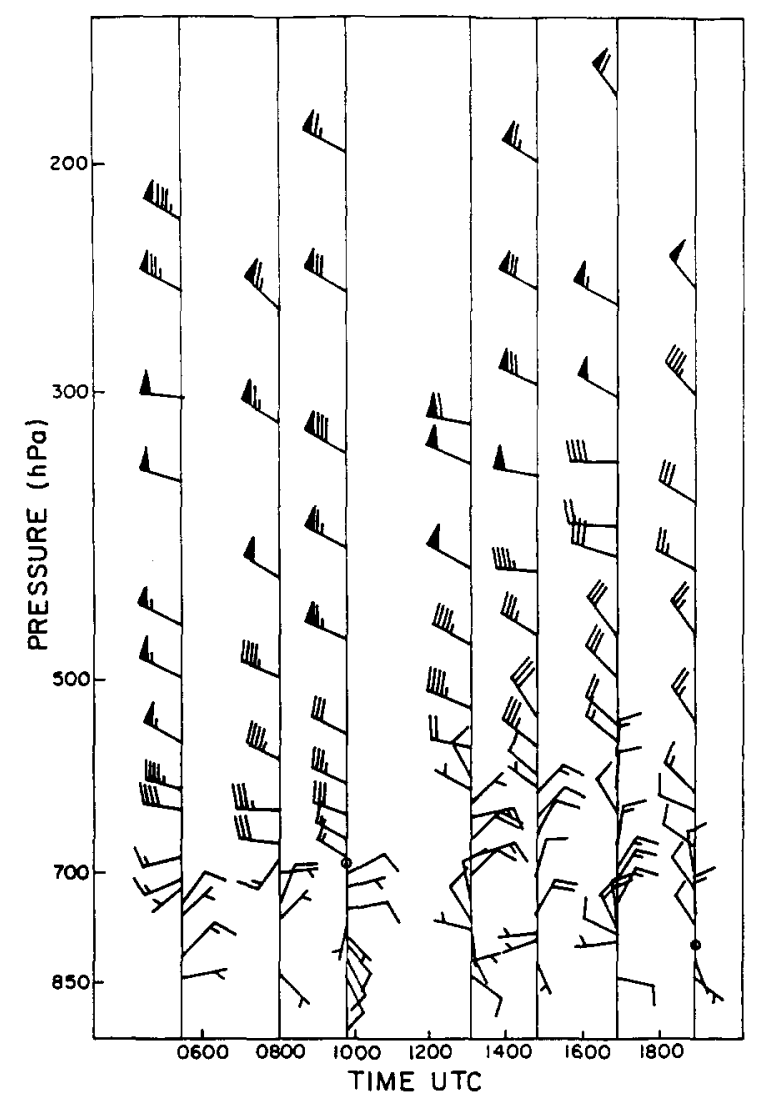

Fig. 14. CLASS wind profiles for the 9-10 February storm. One full wind barb equals $5 \mathrm{~m} / \mathrm{s}$; one flag equals $25 \mathrm{~m} / \mathrm{s}$.

CHR were approximately $1-2^{\circ} \mathrm{C}$ and -6 to $-4^{\circ} \mathrm{C}$, respectively, whereas the corresponding values for the 1985 case were around $-2-0^{\circ} \mathrm{C}$ and -4 to $-2^{\circ} \mathrm{C}$ (see Dunn, 1987, figs. 14-16). The snowfall distribution shown in Fig. 1b for the Front Range exhibited a snowfall maximum roughly $50-80 \mathrm{~km}$ west of the average position of the surface convergence line, depending on latitudinal position along the Front Range. In Dunn's case, the maximum occurred just 15$30 \mathrm{~km}$ west of the convergence line. The moisture content of the inflow may therefore be critical to the evolution of the snowfall event.

The slope of the eastern edge of the dammed cold pool (layer 1 in Fig. 5a) can be estimated for the case of 30-31 March. This sounding indicated the depth of the cold pool to be approximately $250 \mathrm{~m}$ over CHR during much of the heavy snowfall; the snow accumulation maximum was about $30-40 \mathrm{~km}$ from FCL. The convergence line was typically only $25-35 \mathrm{~km}$ away, although it was not clear, due to missing data, whether or not the line remained quasistationary between available observations. A parcel rising dry adiabatically 


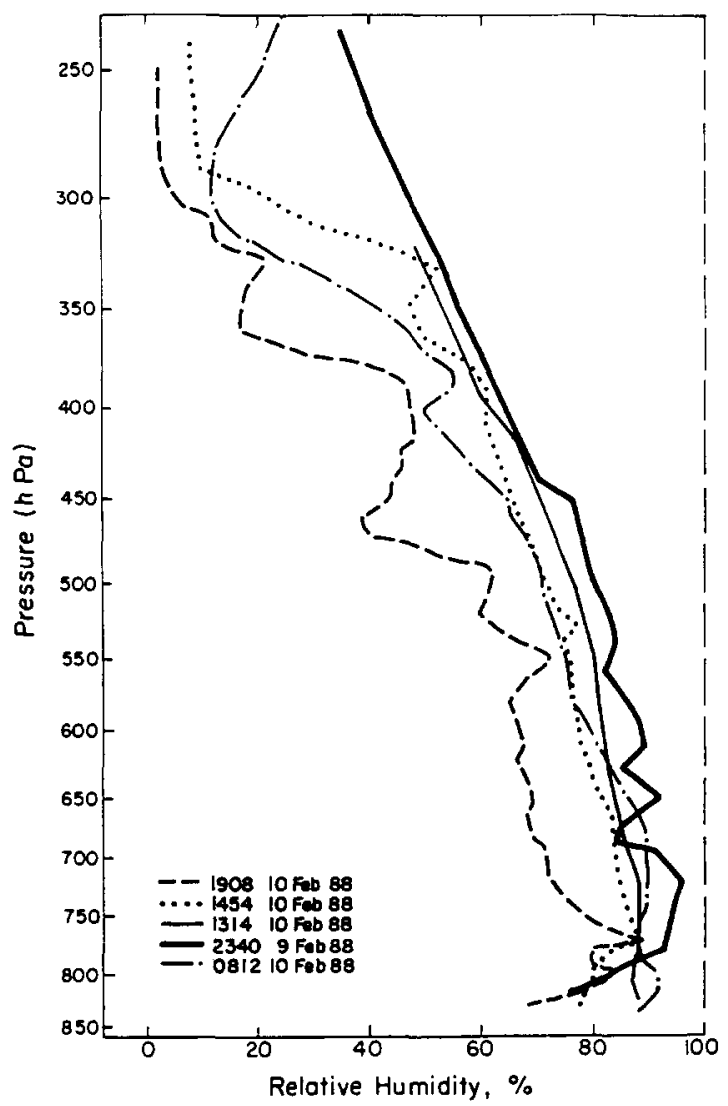

Fig. 15. CLASS relative humidity profiles for the 9-10 February storm.

with the aforementioned initial conditions would reach saturation at a height of approximately $700 \mathrm{~m}$. Extrapolating the sloped lifting surface linearly to the west implies saturation (at $700 \mathrm{~m}$ above the convergence line) approximately $70 \mathrm{~km}$ west of the line; this location is in approximate agreement with the location of the snowfall maximum. Thus, it is probable that the upslope layer is lifted to condensation, creating a liquid water generation region directly above the heaviest snowfall. For this lifted parcel, adiabatic cooling leads to ice saturation at a height of about $600 \mathrm{~m}$ above CHR, or, hypothetically, $60 \mathrm{~km}$ west of the convergence line. These crystals fall into a layer (marked 1 in Fig. 5a), which is near water saturation and has temperatures of -2 to $-5^{\circ} \mathrm{C}$, and thus can grow by deposition, riming and aggregation until they reach the ground. Of course, the winds experienced by the falling snow crystals would exert a significant influence on the location of ground target; however, the soundings in Fig. 6 indicate that they would first advect to the west, and then to the 
southeast in the lowest levels as they fell. Such a trajectory could result in landfall close to an area directly below the crystal generation region.

Some simple thermodynamic calculations of lifting a layer, rather than a parcel, lend support to this hypothesis. Fig. 5a indicates that the layer of easterly winds spans about $200 \mathrm{hPa}$ (or $2 \mathrm{~km}$ ) vertically. Uplift (with constant equivalent potential temperature) of this entire layer, which initially exhibits a temperature range of $1.5^{\circ} \mathrm{C}$ to $-18^{\circ} \mathrm{C}$, would produce a total of approximately $0.2 \mathrm{~cm}$ of liquid condensate. The easterly flow, at about $10 \mathrm{~m} / \mathrm{s}$, would require about two hours to reach from the convergence line to the region of maximum condensation, or about $40-50 \mathrm{~km}$ west of CHR. The resulting hypothetical rate of liquid condensate in this layer if $0.08 \mathrm{~cm} / \mathrm{hr}$, which would account for a significant portion of the snowfall in this storm, even though topographical lifting and large-scale ascent have been ignored for this analysis. Additional time for crystal growth by deposition, riming and aggregation would likely be minor for these saturated conditions (with respect to ice). Observations show that the layered structure in Fig. 5 persists for more than 12 hours.

Hypothetically, using the lifted parcel calculation for the 8-9 December 1985 storm, and a similar cold pool slope for CHR (Dunn, 1987 does not present a thermodynamic sounding) yields saturation at the upper boundary of the cold pool approximately $25 \mathrm{~km}$ west of the convergence line, which is in close agreement with snowfall maxima observations (see Dunn, 1987, figs. 3 and 16; the snowfall maximum occurred $15-20 \mathrm{~km}$ west of the convergence line). Using Dunns' BAO data (Dunn, 1987, fig. 19), the slope of the upper boundary of the cold pool may be steeper than that estimated (about $0.6^{\circ}$ ) for the March storm. As mentioned previously, the convergent regions shown in Fig. 3 are strongest along the northern Front Range, as are the snowfall depths. The vertical motions over the eastern portion of the cold pool probably cause considerable condensate production. In this manner, the location, depth and orientation of the cold pool have a direct effect on the height and location of maximum condensate production, and thus on the precipitation distribution.

For the 9-10 February storm, moisture analysis is more difficult due to the lack of a well-defined convergence line, as well as strong low-level cold advection. Fig. 15 indicates that the upslope air mass was nearly saturated and thus would require only slight lifting to condense. A weak wind shift occurred at the CHR ground station at approximately 0645 UTC (NE to SE; see Table II) as snow intensity was increasing to heavy. No other significant structure to the surface winds occurred other than the previously discussed topographical blocking.

\section{BANDED REGIONS OF HEAVY SNOWFALL}

\subsection{9-10 February 1988 storm}

For the 9-10 February case, the Doppler reflectivity (PPI scans with an elevation angle of $0.7^{\circ}$ ) indicated bands oriented approximately parallel to the 
mean wind shear vector aloft (ie., NW-SE). Fig. 16 shows two examples of reflectivity fields with typical banded structure. The areal extent of the bands (typically two or three coexisting) was approximately $30-80 \mathrm{~km}$ in length and $5-15 \mathrm{~km}$ wide and they persisted over the Front Range and adjacent plains during significant snowfall for this storm. Horizontal band spacing varied from about $10-40 \mathrm{~km}$. The bands appeared to be quasi-stationary for one-half to one hour, and had reflectivity values of typically $15-25 \mathrm{dBz}$. Small (about $5-20 \mathrm{~km}$ largest dimension) cells of additionally enhanced reflectivity repeatedly appeared and dissipated within the bands. These cells within the bands exhibited reflectivity values to $35 \mathrm{dBz}$. Stratiform cloud regions between bands generally produced $5-10 \mathrm{dBz}$ reflectivities. The $30-35 \mathrm{dBz}$ cells, possibly convective, moved along the bands in a southeasterly direction prior to dissipation.

These bands of enhanced reflectivity indicate locations of relatively large precipitation particles. Reports originating from a Citation aircraft flight conducted by researchers at the University of North Dakota (L. Osborne and D. Burrows, pers. commun., 1989) indicated that while significant amounts (a few tenths of $\mathrm{g} / \mathrm{m}^{3}$ ) of liquid water occurred between bands near the frontal inversion at approximately $500 \mathrm{~m}$ above the ground, only the ice phase was found within the bands. The flight occurred from 0700-1300 UTC 10 February 1988 between DEN and Platteville. Apparently ice crystals or aggregates growing to precipitation sizes depleted the liquid water supply within the bands.

As expected, snow intensity observed at CHR for this storm was strongly correlated with the Doppler reflectivity bands, which were observed in the lowest $1 \mathrm{~km}$ of the atmosphere. Table III presents the visibility observed at CHR and the corresponding reflectivity values over CHR on the $0.7^{\circ}$ Doppler PPI scans. The visibility observations are inversely proportional to snowfall intensity, since fog was not reducing visibility by any appreciable amounts and wind speeds were too light to create blowing snow. As shown, heaviest snowfall intensity corresponded with reflectivities greater than $20 \mathrm{dBz}$ at CHR, indicating that the scanned Doppler bands were located at or below precipitation-generation zones. This conclusion is further verified with the surface observations at DEN for the storm. Snowfall there was only light until reflectivity values exceeded $20 \mathrm{dBz}$ over DEN, several hours after the heaviest snowfall at CHR.

The band formation may have been due to frontogenesis or lifting along a frontal surface, although the surface cold front was well south of the region at this time, and no well-defined line of convergence or strong temperature gradient appeared at the surface after this time (see Figs. 11 and 12). Multiple reflectivity bands occurred over the mesonetwork for nearly $12 \mathrm{~h}$ in the postfrontal air mass. The upper air data in this case were not sufficient to detect the exact structure of the frontal surface aloft.

Wolfsberg et al. (1986) report snow-producing bands in a New England winter storm which were aligned with the mean shear vector or thermal wind, as are the bands in this storm. Assuming geostrophic balance in the middle and 

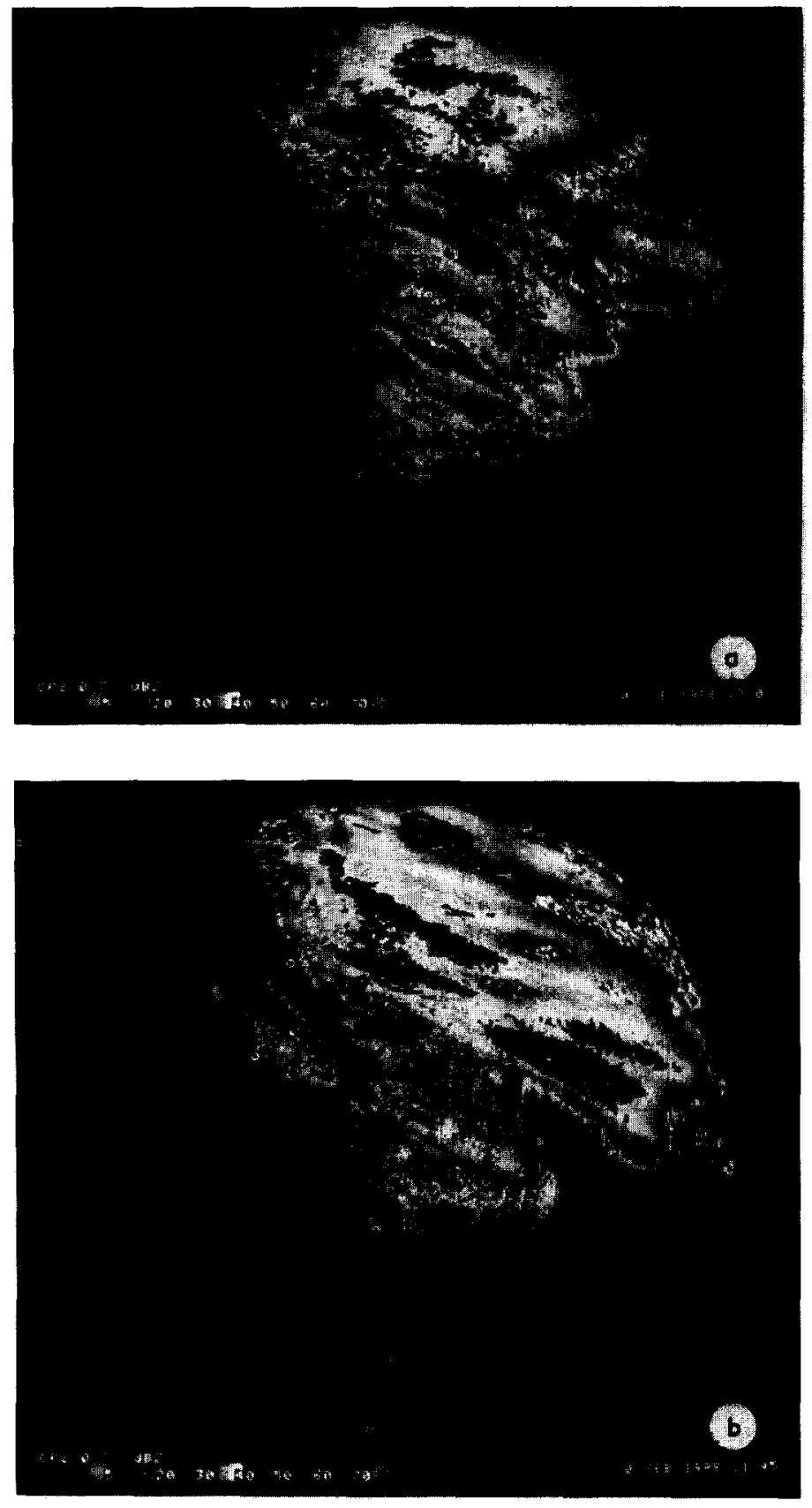

Fig. 16. (a) Doppler reflectivity field for 1001 UTC 10 February 1988 (PPI scan; elevation angle $0.7^{\circ} \mathrm{C}$ ). The center of the scan is just southeast of Boulder. Radius of scan is $100 \mathrm{~km}$. Shades of grey correspond to varying reflectivity values. Dark grey regions within the light grey areas exhibit reflectivity above approximately $23 \mathrm{dBz}$. (b) As in (a) for $1145 \mathrm{UTC}$. 


\section{TABLE III}

Snowfall intensity and Doppler reflectivity at approximately $900 \mathrm{~m}$ above CHR for the $9-10$ February 1988 storm

\begin{tabular}{lll}
\hline $\begin{array}{l}\text { Time } \\
\text { (UTC) }\end{array}$ & $\begin{array}{l}\text { Snowfall } \\
\text { intensity*1 }\end{array}$ & $\begin{array}{l}\text { Reflectivity } \\
(\mathrm{dBz})\end{array}$ \\
\hline 0800 & $\mathrm{H}$ & $20-25$ \\
0830 & $\mathrm{M}$ & 15 \\
0900 & $\mathrm{M}$ & $20-25$ \\
0930 & $\mathrm{H}$ & $25-30$ \\
1000 & $\mathrm{H}$ & 30 \\
1030 & $\mathrm{H}$ & 25 \\
1100 & $\mathrm{M}$ & 25 \\
1210 & $\mathrm{M}-\mathrm{H}$ & 25 \\
1230 & $\mathrm{M}$ & 15 \\
1300 & $\mathrm{M}$ & $10-15$ \\
1330 & $\mathrm{M}$ & $15-20$ \\
1400 & $\mathrm{M}$ & 20 \\
1430 & $\mathrm{M}$ & 20 \\
1500 & $\mathrm{M}$ & 15 \\
1530 & $\mathrm{~L}$ & $10-15$ \\
1600 & $\mathrm{~L}$ & $5-10$ \\
1630 & $\mathrm{~L}$ & $5-10$ \\
1700 & $\mathrm{~L}$ & $2-5$ \\
\hline
\end{tabular}

${ }^{* 1}$ See Table I.

upper troposphere, the $700-500 \mathrm{hPa}$ thermal wind vector at $0540 \mathrm{UTC} 10 \mathrm{Feb}$ ruary for CHR (Fig. 14) is approximately $25 \mathrm{~m} / \mathrm{s}$ at $320^{\circ}$. The $700-500 \mathrm{hPa}$ layer encompasses the upper frontal zone in this storm. Successive directions of this shear vector at $0812,0947,1313,1454,1654$ and 1908 UTC are $290^{\circ}$, $290^{\circ}, 290^{\circ}, 300^{\circ}, 285^{\circ}$ and $300^{\circ}$, respectively. Reflectivity band orientations at these times were also approximately $285^{\circ}-300^{\circ}$ over the mesonetwork from 0800-1400 UTC. The mechanism hypothesized by Wolfsberg et al. for their bands is conditional symmetric instability (CSI), which requires strong vertical shear in a conditionally unstable or neutral environment. Thus it is possible that the same process was occurring in the 9-10 February Colorado case. A storm sounding reported by Wolfsberg et al. (1986, fig. 4) bears a striking resemblance to those of Figs. 13-15 for the February storm, neglecting the lowest $150 \mathrm{hPa}$ for the former sounding. The Colorado case had a strong inversion near $780 \mathrm{hPa}$ (an inversion at $800 \mathrm{hPa}$ was observed in the New England case ) and significant vertical wind shear, strong westerlies aloft and high relative humidities through the lower and middle troposphere. Dunn (1988) reported for a snowstorm in eastern Colorado in September 1985 that the atmosphere had the potential for CSI to operate in a broad region in the atmo- 
sphere at heights of about 4-8 $\mathrm{km}$. A heavy snowband was also observed in this storm, as well as a distinct temperature inversion at approximately $700 \mathrm{mb}$.

The complex terrain present in the Front Range region obviously creates a much more involved situation for a complete analysis of the role of CSI or frontal forcing and would benefit from the use of a mesoscale numerical cloud model, or soundings observed at a much finer horizontal resolution. Such an analysis would require some consideration of the effect of topography on the strong mid-level westerly winds present in this storm.

The Doppler radial velocity fields for the $0.7^{\circ} \mathrm{PPI}$ scans provide additional insight into the banded reflectivity structure. Fig. 17 shows an example of one of these scans (1615 10 February 1988). The CHR soundings (Fig. 14) contained winds at a height of $900 \mathrm{~m}$ which agreed with the Doppler radial velocity measured at this point. At several times, (e.g., 0915, 1015 and 1430 UTC) bands of enhanced reflectivity corresponded well with converging radial winds, but only for those bands located at the outer regions of the scan. This correspondence occurred for bands located more than about $50 \mathrm{~km}$ from the radar. Apparently, the enhanced reflectivity bands were manifestations of positive vertical motions above a height of at least $0.6 \mathrm{~km}$ (i.e., precipitation particles generated above the Doppler scan ). The $25-35 \mathrm{dBz}$ cells within the bands also

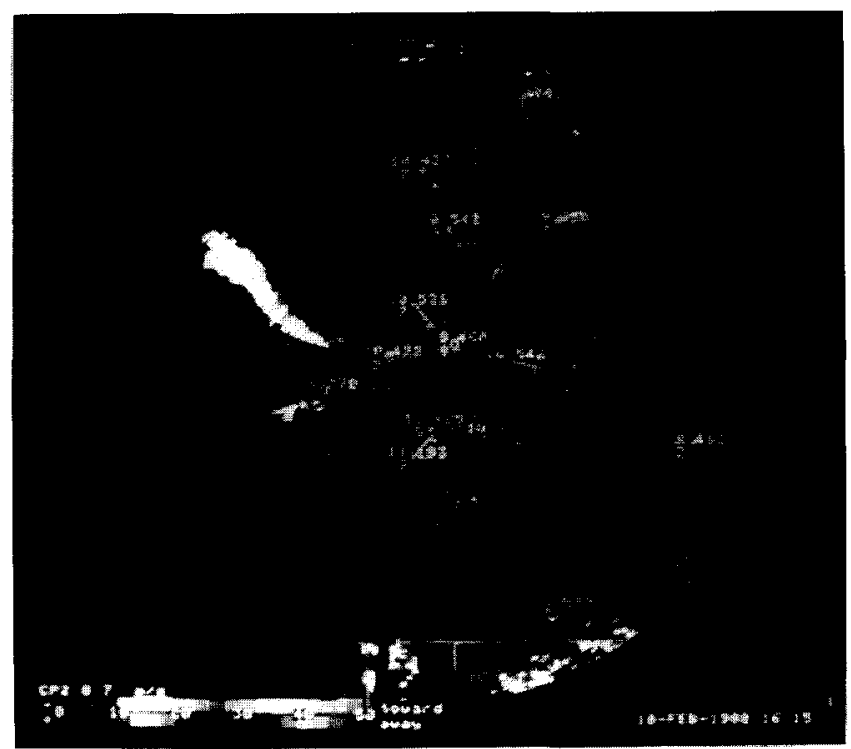

Fig. 17. Doppler radial velocity field for 1615 UTC 10 February 1988 (PPI scan; elevation angle $0.7^{\circ}$ ). Shades of grey correspond to varying radial velocity magnitudes toward and away from the radar. Structure (i.e., changing shades over short distances) in a given radial direction indicates areas of convergence and divergence, as discussed in the text. Surface observations are in standard format for the PROFS mesonetwork. 
correlated with strong convergence above $0.6 \mathrm{~km}$. For example, at 1015 UTC, $15 \mathrm{~m} / \mathrm{s}$ northerly winds at a height of $0.7 \mathrm{~km}$ converged with near-calm regions in the same area as $30 \mathrm{dBz}$ reflectivity measurements above a location a few $\mathrm{km}$ west-northwest of CHR. At 0915 UTC, strong convergence was also observed at $1.0 \mathrm{~km}$ in a band of enhanced reflectivity. Marked divergence was observed $10 \mathrm{~km}$ south of this area. However, at heights below $0.6 \mathrm{~km}$, even weak divergence or nondivergent flow occurred in bands of enhanced reflectivity located closer than $50 \mathrm{~km}$ from the radar.

Lilly (1981) reported reflectivity maxima (around $20 \mathrm{dBz}$ ) near the surface for the upslope storm of 9-10 February 1981, as well as low-level features of alternately increased and decreased velocity (horizontal scale of a few $\mathrm{km}$ ) in the radial velocity fields parallel to the mean wind direction. Above the arctic air, he also observed convergence/divergence features in the radial velocity field which were parallel to the mean shear vector, as in the present cases.

There are other possible explanations for the banded structure observed in the reflectivity fields in the 10 February 1988 storm which deserve further attention. Rauber et al. (1986) reported favored droplet nucleation zones just upwind of mountain peaks in northern Colorado. Significant droplet or crystal nucleation zones near the mountain peaks upstream of the Front Range and subsequent crystal growth in bands downstream is unlikely, since the soundings in Fig. 14 reveal only weak to nonexistent cross-barrier winds at mountain-top $(650-600 \mathrm{hPa})$ during the banding periods of $0700-1700 \mathrm{UTC}$. Of course, zones of ascent aloft associated with mountain-induced gravity waves may have nucleated crystals some distance above the mountaintops. Lee waves may also have been present over the Front Range during this storm, in association with the strong inversions (Fig. 13b). It is not clear at this point if these topographically-induced waves could create the intense banding observed. It is clear, however, that the bands continually appeared and disappeared over various locations along the Front Range.

\subsection{0-31 March 1988 storm}

During the early portions of the storm on the evening of $30 \mathrm{March}$, surface observations taken at CHR indicated oscillations of wind direction from easterly to northwesterly; these seemed to have an approximate period of a few hours (see Table I). The convergence line, discussed in Section 3, may have been crossing the area during this time, producing changing wind directions (see the northeasterly surface winds in Fig. 6 for 0127 UTC). Examination of the surface analyses in Fig. 3 revealed some movement of the convergence line with time. Snow intensity observations taken at the corresponding times also indicated some oscillation from moderate to heavy, although not clearly in phase with the wind direction. Generally, heavy snow was observed at CHR during the brief periods of northwest winds (see Table I). This observation is not surprising, considering the vertical storm structure described previously, 
where lifting along the upper portion of the cold pool was suggested to create the heavy snowfall.

For the 30-31 March 1988 case, CP-2 Doppler radar measurements, as in the February storm, indicated a banded reflectivity structure during the early portion of the storm, with approximate north-south band orientation and movement to the west-northwest into the northern portion of the mesonetwork. The mean $700-500 \mathrm{hPa}$ shear vector at $\mathrm{CHR}$ (this layer encompasses the upper frontal zone for most of the storm; see Fig. 6) was oriented approximately north-south at 0800 UTC 31 March, during heavy snowfall. The orientation at the other sounding times was approximately $030^{\circ}$. Reflectivity maxima were about $30 \mathrm{dBZ}$. The bands appeared to be approximately $10 \mathrm{~km}$ wide, 25 to $75 \mathrm{~km}$ long and traceable for the entire horizontal range of the radar. The snow intensity observed at Fort Collins increased markedly as the bands passed through the region. PPI radar scans at $0.2^{\circ}$ showed generally stronger reflectivity maxima than those at $0.7^{\circ}$; thus these precipitation cores may indeed have been generated in the lower regions of layer 2 in Fig. 5a, as discussed previously. The $0.2^{\circ}$ scan crosses a vertical column about $250 \mathrm{~m}$ above the ground at $\mathrm{CHR}$, and the $0.7^{\circ}$ scan at $900 \mathrm{~m}$. Stronger reflectivities are thus observed near the upper portion of the cold pool at CHR and may be related to the enhanced upward motion created as the upslope layer rises over the dammed cold pool. Some bands of enhanced reflectivity aloft were observed in regions well east of the convergence line, where heavy snowfall did not occur. This observation implies that both lifting at the eastern edge of the cold pool and snow crystal trajectories through the nearly saturated cold pool are critical for heavy snowfall. Dopper velocity scans were not available for this storm.

\section{INTERPRETATION OF SNOW CRYSTAL TYPES}

Observations of snow crystal types provide additional insight into the precipitation mechanisms discussed previously. During the 30-31 March storm, the spotter network reported predominantly aggregated, heavily-rimed spatial dendrites, as well as several 15- to 30-min graupel episodes. Table IV presents the preliminary results of these reports. Many of the dendrites making up the large aggregated snowflakes contained heavily rimed single crystals in their cores. This tendency for riming to be concentrated near the centers of the individual dendrites rather than the branches implies that liquid water was present in layer 3 (see Fig. 5a), with subsequent dendritic crystal growth occurring in layer 2 . The observation may be the result of liquid water accumulation near cloud top, as in the northern Colorado mountain cloud systems reported in Rauber et al. (1986). Unrimed and unaggregated crystals comprise only about $9 \%$ of the observations. These results indicate that liquid water layers played a significant role in precipitation production, although the exact 


\section{TABLE IV}

Snow crystal observations for the spotter network shown in Fig. 1b for the 30-31 March 1988 storm

\begin{tabular}{ll}
\hline Crystal type & $\begin{array}{l}\text { Total no. } \\
\text { occurrences }\end{array}$ \\
\hline Heavily rimed, aggregated spatial dendrites & 41 \\
Heavily rimed irregulars & 29 \\
Graupel & 18 \\
Rimed, aggregated plates & 11 \\
Rimed sector plates & 9 \\
Heavily rimed stellars & 7 \\
Unrimed stellars & 4 \\
Lightly rimed dendrites & 4 \\
Unrimed plates & 3 \\
\hline
\end{tabular}

nature of this role (e.g. the location of these layers) is not readily determinable from these data.

Therefore, the predominance of significant dendritic growth implies that layer 2 probably contained areas of upward motion (needed to obtain nearly saturated conditions with respect to liquid water, and thus favored dendritic growth), as discussed previously. The moist layer 3 may be a crystal generator region, reaching ice saturation as uplift occurs. The soundings in Figs. 5 and 7 indicate slight supersaturation with respect to ice at $-30^{\circ} \mathrm{C}$. Layer 3 , too cold for dendritic growth, probably produced platelike or columnar crystals which may have been masked by riming prior to descent into layer 2. Crystals nucleating in this layer could serve as cores for further riming and dendritic growth below.

For the 9-10 February case, snowflakes at CHR during the significant snowfall were also predominantly aggregated, heavily rimed spatial dendrites. A few of the aggregates were made up of planar dendrites. Irregular crystals comprised many of the aggregates, unidentifiable primarily due to the heavy riming; at times, the crystals had nearly enough riming to be considered graupel. Maximum aggregate diameters were typically $10-15 \mathrm{~mm}$ during the first few hours of heavy snowfall (approximately 0700-1100 UTC), and about 2-5 mm afterwards. The large rimed dendrites early in the storm probably grew to precipitation sizes well above the $700 \mathrm{hPa}$ inversion shown in Fig. 13a for 0812 and 0957 UTC. The temperature range conducive to dendritic growth at these times is confined to regions above $700 \mathrm{hPA}$. Some heavy snowfall occurred prior to 0957 UTC. The westerlies aloft (analogous to the southerlies in the 30-31 March case) experienced lifting over the region for several possible reasons: topography, ascent on the synoptic scale, and overrunning above the eas- 
terlies in the low levels. Since this air mass was near water saturation and supersaturated with respect to ice, it probably was a crystal generator region, as in the March case. Lilly (1981) reports significant precipitation particle generation in the overlying westerlies in the 9-10 February 1981 upslope storm. After passage of the arctic front, it is likely that further dendritic growth occurred in the cold pool in the present case (Fig. 13b). Aircraft reports (UND Citation) for the storm indicated persistent liquid water at and below the inversion at the upper boundary of the arctic air mass (Fig. 13b). Liquid water amounts of a few tenths of $\mathrm{g} / \mathrm{m}^{3}$ were measured for more than two hours. The predominance of heavily rimed crystals at the ground confirms the importance of these liquid water layers for precipitation growth. The aircraft detected no liquid water amounts within the previously discussed enhanced reflectivity bands, as ice crystals produced above the scans rapidly depleted droplet populations in the lowest $1 \mathrm{~km}$ of the atmosphere.

\section{OBSERVATIONS OF STORM TERMINATION}

The CHR soundings of Figs. 5-7 enable some assessment of the temporal evolution of the snow production processes in the 30-31 March 1988 snow event. Cold air damming, as well as snowfall, did not become significant until several hours after the upslope flow began (see the soundings in Fig. 6, where upslope flow extended from the surface to $580 \mathrm{hPa}$ ). However, cold air damming persisted at about the same strength for more than $12 \mathrm{~h}$ (note the similarity in low-level winds at 0427, 0812 and 1321 UTC 31 March, Figs. 6). The strong frontal inversion $(550-500 \mathrm{hPa})$ developed, strengthened and rose slightly during the storm progression. The mid-level easterly flow was persistently moist and strong, reaching approximately $12.5 \mathrm{~m} / \mathrm{s}$ near the end of the period of moderate to heavy snow intensity at CHR. This flow may be equivalent to the "cold conveyor belt" which frequently develops in midwestern and east coast snowstorms (see Iskenderian, 1988). In the Colorado case, this lowto mid-level moist easterly flow was lifted over the dammed layer.

The southerlies (above $500 \mathrm{hPa}$ for the March storm), a product of synopticscale flow around the cutoff low to the southwest, exhibit some change in direction and speed during the storm, beginning at $170^{\circ}$ (0127 UTC), veering to $210-220^{\circ}$ at $0427 \mathrm{UTC}$ and back to $190-200^{\circ}$ four hours later. As mentioned previously, this moist air (temperatures -20 to $-35^{\circ} \mathrm{C}$ ) probably acted as a crystal generator region for the storm, and coupled with the mid-level upslope constituted an efficient seeder-feeder process over the Front Range region. These crystals, acting as a natural seeding mechanism, could be particularly important for snow events in which clouds in the blocked layer and the upslope flow are too warm to naturally glaciate, as is sometimes the case.

The last CLASS sounding, released at 1710 UTC 31 March as the snowfall at CHR was decreasing indicated some significant trends which could explain the conclusion of heavy snowfall (Figs. 5-7). Although cold air damming per- 
sisted as evident by the low-level northwesterly flow over the Front Range, the mid-level upslope weakened and became discontinuous in the vertical; the easterly component of upslope flow had decreased by $25-50 \%$ in magnitude; the layer also cooled by several ${ }^{\circ} \mathrm{C}$ and moisture content decreased rapidly in a relative and absolute sense. The upper portion of this layer (700-550 hPa) stabilized significantly, as shown in Fig. $5 \mathrm{~b}$. A decrease in wind speed by $5-10$ $\mathrm{m} / \mathrm{s}$ occurred above the frontal inversion (Fig. 6 ), which lost most of its identity by 1700 UTC. Layer 3 also became much drier than in the previous sounding (Fig. 7), indicating that the seeder-feeder process probably had ceased by this time. FCL and CHR received only light snow afterwards. The 0000 UTC 1 April sounding for Denver also indicated that as the snowfall subsided, the southerlies weakened significantly. It is not clear if the snowfall subsided when this warm, moist flow lost its large-scale upward motion, or when uplift over layer 2 subsided.

As mentioned previously, the 9-10 February case did not exhibit significant cold air damming. As a result, no well-defined upstream convergence line formed. As shown in Fig. 13, the frontal inversion aloft, strong at 0540 UTC, weakened and moved from about $730 \mathrm{hPa}$ to above $650 \mathrm{hPa}$ during the storm. The associated moist northeasterly flow in the layer below the upper inversion actually strengthened to $7.5-10 \mathrm{~m} / \mathrm{s}$ at 1314 UTC. Later, as it turned northerly, weakened and became less moist, the snow intensity decreased at CHR. This observation again indicated the importance of the lifting of this upslope layer. The upper-level west-northwesterly winds were strongest during the height of the storm, and weakened significantly after 1700 UTC, similar to the 30-31 March case, but did not change direction. Another similarity was the drying aloft during the weakening portion of the storm. This crystal generator region apparently depended on available moisture.

The low-level arctic air mass in this storm did not exhibit a well-defined frontal boundary. The colder air filtered into the Front Range region beginning about 0600 UTC. The depth of the cold air increased to about $700 \mathrm{~m}$ over CHR at 1314 UTC (Fig. 13) and actually decreased to about $400 \mathrm{~m}$ at 1654 UTC with nearly constant depth for the next few hours. The tendency of the arctic air mass to remain in place, despite strong westerly flow aloft, was investigated numerically by Lee et al. (1989), who found that in the absence of surface heating, either shear-induced mixing at the upper boundary of the air mass or a large scale surface pressure gradient force leading to a westerly geostrophic wind (not present here for many hours after the snow subsided) are required for the mid-and upper-level westerlies to reach the ground. Lilly (1981) notes for the 9-10 February 1981 case that the amount of entrainment at the upper boundary of the cold mass air is critical to both the persistence of the cold upslope and the amount of low-level blocking present. In the present case, the time period of a relatively high inversion (around 1314 UTC), implying re- 
duced entrainment, was followed by upstream deceleration (Fig. 11c,d), agreeing with the comments of Lilly.

\section{CONCLUSIONS}

Observations of Colorado Front Range snowstorms during the past winter have revealed some intriguing characteristics of snowfall in complex terrain. Case studies of the 30-31 March and 9-10 February 1988 storms indicate multilayer wind and temperature vertical profiles which have direct implications toward the cloud dynamical and snow crystal production processes:

(1) The vertical structure for the March case includes a shallow layer of cold air which dams and induces uplift of deep, moist upslope flow. The eastern edge of this layer formed a well-defined convergence zone at the surface east of the foothills.

(2) Analysis and comparison of snowfall data and locations of the blockinginduced convergence line indicate that the moisture content of the low-level upslope flow is critical to the location of heavy snowfall in the cold air damming events. Upon comparison of the March storm and the December event described by Dunn (1987), it is apparent that initially drier upslope flow is associated with snowfall maxima further to the west.

(3) The February storm exhibited no cold air damming, but some topographical blocking, which created weak convergence zones and enhanced precipitation east of the foothills.

(4) Blocking by cold pools or topography can be important for the precipitation along the Colorado Front Range for both the shallow upslope with westerly flow aloft and the deeper upslope with southerly flow aloft.

(5) Predominant snowflake types for both storms were heavily-rimed, aggregated spatial dendrites. Low- and mid-level moist upslope flow was apparently seeded by crystal generation zones aloft. Rapid dendritic growth occurred in the upslope flow for both cases and continued in the low-level arctic air mass in the February case. Precipitation termination in both cases occurred as upslope flow above the surface weakened and the upper air mass (above the frontal inversion aloft) became drier.

(6) Both cases produced banded Doppler reflectivity structures, with band orientation approximately parallel to the thermal wind vector. Bands were correlated with observed snowfall intensity.

(7) Analyses of these storms, and the case study presented by Dunn (1987), show that these types of low-level convergence occur frequently along the Front Range during winter upslope events.

From a forecasting standpoint, more research is required to quantitatively assess the physical processes which determine the strength and slope of the cold pool. The problem of localized convergence caused by a blocking-induced cold pool is well-known among forecasters in the Front Range region (Dunn, 
1987). Given the initial low-level stability, the strength and direction of the upslope flow, and its moisture content, the forecaster may have a better understanding of the location of heavy snowfall (specifically, its east-west extent). Indications based on the storms discussed in this paper are that blocking creates distinctly different convergence zones for situations in which the lowest layers are very cold (e.g., after the passage of a shallow arctic cold front), as opposed to the deep upslope storms. To investigate the microphysical and dynamical aspects in more detail, aircraft and Doppler radar data are undergoing further analysis for several other storms.

This type of research deals directly with a more general problem evident in atmospheric science at this time; specifically, this is the understanding of physical processes involved in mesoscale precipitating systems. Snowfall distributions in complex terrain persistently exhibit significant variations on spatial scales of a few to $50 \mathrm{~km}$, and much more research is required to quantitatively assess all of the causes of this variability. The present study will benefit the understanding of snowstorm microphysical and dynamical processes both in Colorado and other regions of complex terrain.

\section{ACKNOWLEDGEMENTS}

The authors would like to express their appreciation to the Army Research Office, under contract number DAAL03-86-K-0175, for support of this research at the Center for Geosciences at Colorado State University. The Office of Naval Research provided the CLASS sounding facilities under contract N00014-87-K-02281/P00001. Bill Cotton, Paul Schultz, Lawrence Dunn, Jim Wirshborn, Steve Cox, Chris Johnson-Pasqua, Tim Alberta, John Kleist, and Paul Wolyn assisted with the observational program. Other contributions to this research effort include PROFS, and the SERS (Storm Education and Research System) at CSU. SERS is sponsored by the Cooperative Institute for Research in the Atmosphere. Leon Osborne and Don Burrows of the University of North Dakota kindly provided some key microphysical information from one of their Citation aircraft flights. Ms. Judy Sorbie drafted the figures and Ms. Dallas McDonald helped type and proofread the manuscript. The authors also thank the anonymous reviewers for their suggestions for revisions.

The following snow spotters provided critical snow and weather observations for this study: John Weaver, Ray Zehr, Rita Ederveen, Glen Cobb, Jim Wirshborn, Greg Stumpf, Lewis Grant, Nolan Doesken, Mike Meyers, John Jepsen, Willa Hintergardt, Edward Halbach, Kenneth King, Betty Covalt, Dean and Judith Brungardt, Robert Kretchmer, Edward Epler, Sue Rehfeld, Ernie Conrad, Mollie Scheller, Roger Bullene, Robert Dorn, Leslie Burns, Greg Winter, Christina Andre, Jim and Nancy Digby, Phyllis Honholtz, Lawson and Glenda Casad, Bob Dunckhorst, Wilfred Dodds, Van Polowchak, Duane Lewis, 
Paul Henderson, Don Teem, and Randy and Molly Pierce. Without these observations, many mesoscale details of the storms would remain a mystery.

\section{REFERENCES}

Boatman, J.F. and Reinking, R.F., 1984. Synoptic and mesoscale circulations and precipitation mechanisms in shallow upslope storms over the western High Plains. Mon. Weather Rev., 112: 1725-1744.

Bosart, L.F., 1975. New England coastal frontogenesis. Q. J. R. Meteorol. Soc., 101: 957-978.

Dunn, L., 1987. Cold air damming by the Front Range of the Colorado Rockies and its relationship to locally heavy snows. Weather Forecasting, 2: 177-189.

Dunn, L., 1988. Vertical motion evaluation of a Colorado snowstorm from a synoptician's perspective. Weather Forecast., 3: 261-272.

Heggli, M.F. and Rauber, R.M., 1988. The characteristics and evolution of supercooled water in wintertime storms over the Sierra Nevada: A summary of microwave radiometric measurements taken during the Sierra Cooperative Pilot Project. J. Appl. Meteorol., 27: 989-1015.

Iskenderian, H., 1988. Three-dimensional airflow and precipitation structure in a nondeepening cyclone. Weather Forecasting, 3: 18-32.

Juisto, J.E., 1967. Nucleation Factors in the Development of Clouds. Ph.D. Thesis, Penn State University, University Park, Penn, 124 pp.

Lee, T.J., Pielke, R.A., Kessler, R.C. and Weaver, J., 1989. Influence of cold pools downstream of mountain barriers on downslope winds and flushing. Mon. Weather Rev., 117: 2041-2058.

Lilly, D.K., 1981. Doppler radar observations of upslope snowstorms. Prep., 2nd Conf. Mountain Meteorology, AMS, Steamboat Springs, Colo, Nov. 1981. pp. 346-353.

Parish, T., 1982. barrier winds along the Sierra Nevada mountains. J. Climate Appl. Meteorol., 21: 925-930.

Rauber, R.M., Feng, D., Grant, L.O. and Snider, J.B., 1986. The characteristics and distribution of cloud water over the mountains of northern Colorado, Part I. Temporal variations. J. Climate Appl. Meteorol., 25: 468-488.

Reinking, R.F. and Boatman, J.F., 1986. Upslope precipitation events. In: P.S. Ray (Editor), Mesoscale Meteorology and Forecasting. AMS, Boston, Mass., pp. 437-471.

Schlatter, T.W., Baker, D.V. and Henz, J.F., 1983. Profiling Colorado's Christmas Eve blizzard. Weatherwise, 36: 60-66.

Schultz, P., McCoy, M.C., McGowan, R.W. and Wakfield, J.S., 1985. The first experiment in forecasting cool-season weather with the PROFS system. NOAA Tech. Mem., ERL ESG-16, April 1985.

Toth, J.J., 1987. Interaction of shallow cold surges with topography on scales of 100-1000 kilometers. CIRA Publication, Colorado State University, Fort Collins, Colo., ISSN No. 0737$5352-8,135$ pp.

Wesley, D.A. and Pielke, R.A., 1988. A numerical model simulation of cold air damming along the Colorado Front Range. Proc. 2nd Int. Cloud Modelling Workshop, August 8-12, 1988, Toulouse.

Wesley, D.A., Weissbluth, M.J., Pielke, R.A. and Cotton, W.R., 1988. Microphysical and dynamical interactions in Colorado Front Range upslope storms. Preprints 10th Int. Cloud Physics, Conf., August 15-20, 1988, Bad Homburg, Vol. I, pp. 359-361.

Wolfsberg, D.G., Emanuel, K.A. and Passarelli, R.E., 1986. Band formation in a New England winter storm. Mon. Weather Rev., 114: 1552-1569. 